\title{
The Long-Term Acceleration of Waste Glass Corrosion: A Preliminary Review (U)
}

July, 1995

Westinghouse Savannah River Company Savannah River Technology Center Aiken, SC 29808

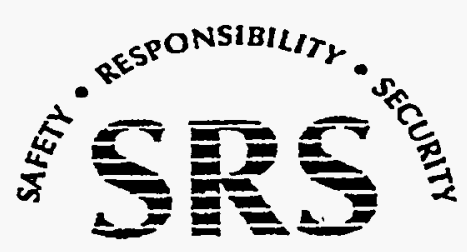

PREPARED FOR THE U.S. DEPARTMENT OF ENERGY UNDER CONTRACT NO. DE-AC09^89SR18035 


\section{DISCLAMMER}

This report was prepared as an account of work sponsored by an agency of the United States Govermment. Neither the United States Government nor any agency thereof, nor any of their employees, makes any warranty, express or implied, or assumes any legal liability or: -responsibility for the accuracy, completeness, or usefulness of any information, apparatus, product, or process disclosed, or represents that its use would not infringe privately owned rights. Reference herein to any specific commercial product, process, or service by trade name, trademark, manufacturer, or otherwise does not necessarily constitute or imply its endorsement, recommendation, or favoring by the United States Government or any agency thereof. The views and opinions of authors expressed herein do not necessarily state or reflect those of the United States Government or any agency thereof.

This report has been reproduced directly from the best available copy.

Available to $D O E$ and $D O E$ contractors from the Office of Scientific and Technical Information, P.O. Box 62, Oak Ridge, TN 37831; prices available from (615) 57.6-8401.

Available to the public from the National Technical. Information Service, U.S. Department of Commerce, 5285 Port Royal Road, Springfield, VA 22161. 


$\begin{array}{ll}\text { Key Words: } & \text { Accelerated Corrosion } \\ & \text { Durability } \\ & \text { PCT } \\ & \text { Glass } \\ & \text { LLW }\end{array}$

Retention: Lifetime

\section{The Long-Term Acceleration of Waste Glass Corrosion: A Preliminary Review (U)}

\section{A. L. KIELPINSKI}

July, 1995

Westinghouse Savannah River Company Savannah River Technology Center Aiken, SC 29808

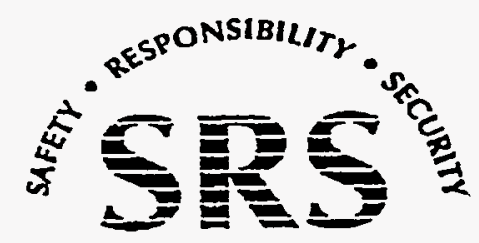

PREPARED FOR THE U.S. DEPARTMENT OF ENERGY UNDER CONTRACT NO. DE-AC09-89SR18035 
Project:

Document:

Title:
Hantord LLW

WSRC-TR-95-0306

The Long-Term Acceleration of Waste Glass Corrosion: A Preliminary Review (U)

Approvals:

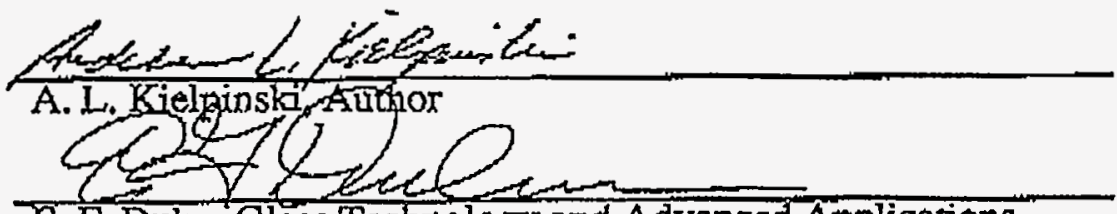

E. F. Duhn, Glass Technology and Advanced Applications

bet feiluerk

J. FGbtook, WHC Customer Representative
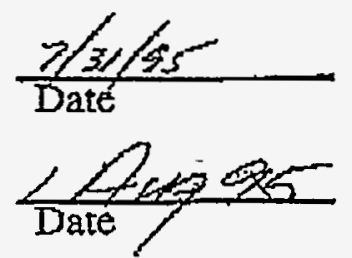

$\frac{8 / 14 / 95}{\text { Date }}$ 


\section{TABLE OF CONTENTS}

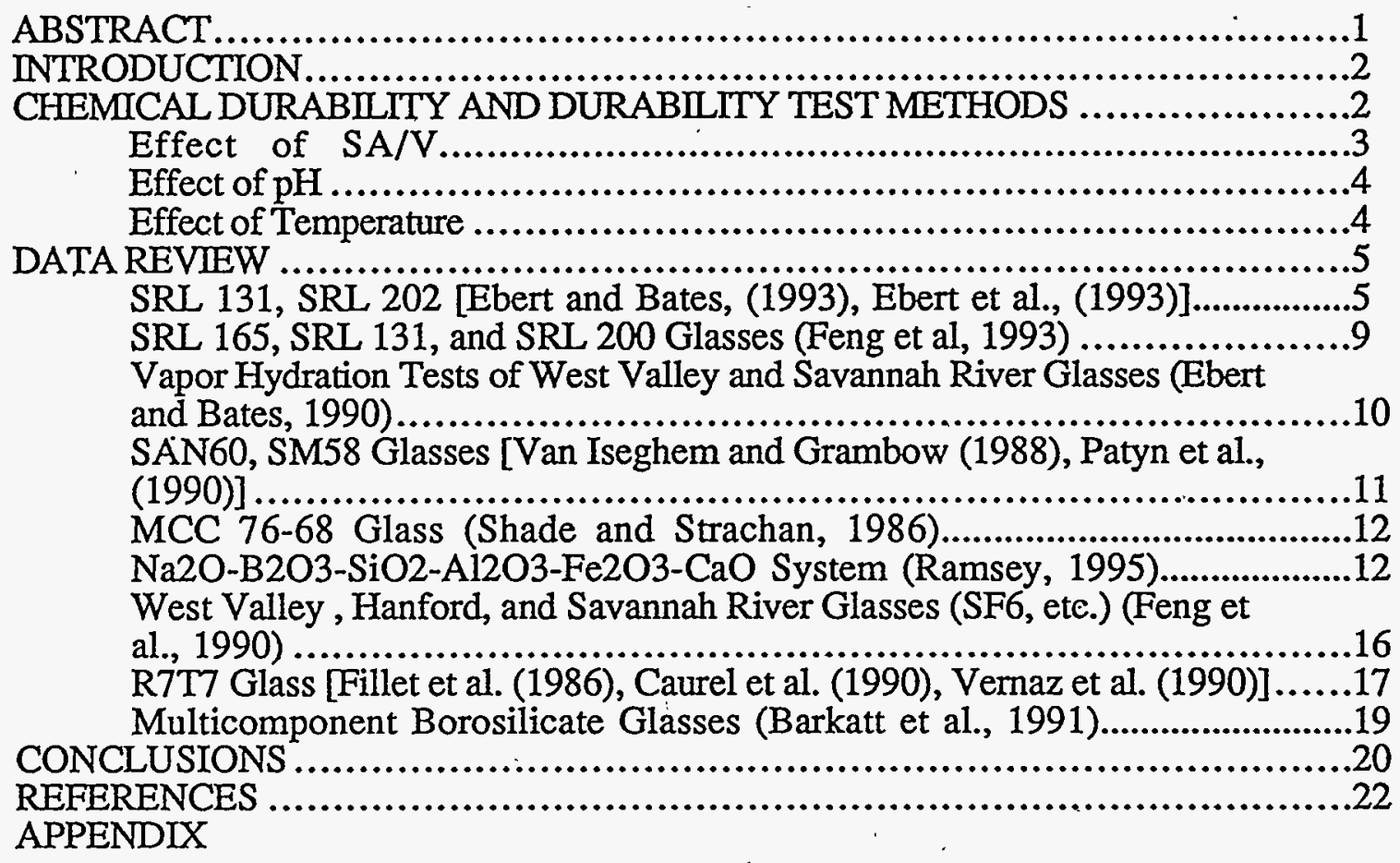




\begin{abstract}
The quality and integrity of glass as a wasteform for immobilizing radioactive waste is principally assessed in terms of its chemical durability. An area of emerging concern is that of the long-term dissolution rate of the glass. Whereas a prior conception of glass dissolution posited a relatively rapid initial dissolution which then slowed to a smaller, fairly constant, "long-term" rate, some recent work suggests that these two stages are followed by a third phase of dissolution, in which the dissolution rate is accelerated with respect to what had previously been thought of as the final long-term rate. The goals of the present study are to compile experimental data which may have a bearing on this phenomena, and to provide an initial assessment of these data. The Savannah River Technology Center (SRTC) of Westinghouse Savannah River Company (WSRC) is contracted to develop glass formulation models for vitrification of Hanford low-level waste (LLW), in support of the Hanford Tank Waste Remediation System Technology Development Program. Therefore, this assessment of accelerated corrosion data, conducted as part of the Hanford LLW glass formulation program, emphasizes the relevance of the phenomenon to glass compositions of interest for vitrification of the highsodium, low-level wastes at the Hanford reservation.
\end{abstract}

The phenomenon of an increase in corrosion rate, following a period characterized by a low (sometimes negligible) corrosion rate, has been observed by a number of researchers on a number of waste glass compositions. Despite inherent ambiguities arising from $S A / V$ and other effects, valid comparisons can be made in which accelerated corrosion was observed in one test (for a given glass composition), but not in another. Some glass compositions do not appear to attain a plateau region (cf. Figure 1); it may be that the observation of continued, non-negligible corrosion in these glasses represents a passage from the initial rate ("Phase 1") to the "accelerated" rate ("Phase 3"). The long-term corrosion is a function of the interaction between the glass and its environment, including the leaching solution (its chemistry, volume, and flow) and the surrounding materials. Reaction path modeling and stability field considerations have been used with some success to predict the changes in corrosion rate over time, due to these interactions. The accelerated corrosion phenomenon highlights the need for such integrated corrosion modeling and the scenario-specific nature of a particular glass composition's durability. 


\section{INTRODUCTION}

The quality and integrity of glass as a wasteform for immobilizing radioactive waste is principally assessed in terms of its chemical durability. The concept of durability is defined in a number of ways. Ultimately, however, a glass wasteform must prove resistant to aqueous attack, dissolution, and release of immobilized constituents, within a given repository environment and for a time period much longer than that of any man-made test.

Various test procedures have been developed which measure some aspect of chemical durability. Candidate waste forms may be ranked differently according to which test is used. An area of emerging concern is that of the long-term dissolution rate of the glass. Whereas a prior conception of glass dissolution posited a relatively rapid initial dissolution which then slowed to a smaller, fairly constant, "long-term" rate, some recent work suggests that these two stages are followed by a third phase of dissolution, in which the dissolution rate is accelerated with respect to what had previously been thought of as the final long-term rate.

At present, only a small amount of experimental data show this third characteristic rate of glass dissolution, and its explanation has not been established. That is, it is not clear how the observed acceleration depends on glass composition, on various features of the particular test method(s) used, and so forth. The goals of the present study are to compile experimental data which may have a bearing on this phenomena, and to provide an initial assessment of these data. In particular, the assessment will emphasize the relevance of this phenomenon to glass compositions of interest for vitrification of the high-sodium, lowlevel wastes at the Hanford reservation.

\section{CHEMICAL DURABILITY AND DURABILITY TEST METHODS}

Qualitative features of the glass dissolution process are shown in Figure 1. This picture of the dissolution process has been. formed from experiments on silicate glasses containing significant amounts of alkali metals and, most often, a significant amount of boron as well. Such glass compositions are typical of those considered for the immobilization of highlevel radioactive waste at various disposal sites world-wide. Borosilicate glasses are also strong contenders for immobilization of a large portion of the Hanford LLW, much of which is high in sodium. "Phase 1 " of the dissolution process is characterized by rapid glass dissolution at the so-called "forward" rate, with a release of alkali metals and concomittant rise in leachate $\mathrm{pH}$. "Phase 2 " is characterized by a slowdown in rate, variously attributed to pseudo-saturation of the leachant by silicic acid and/or to buildup of alteration layers on the glass surface which inhibit further dissolution. Note that, while some researchers have reported a slowdown of corrosion to essentially zero, others have reported (for other compositions) a continued, significant rate of dissolution. Moreover, the rate corresponding to "Phase 2 " has been found by some researchers to be a function of the test conditions, specifically, the ratio of glass surface area to leaching solution volume (Vernaz et al., 1990). Thus, not all compositions behave according to the model pictured in Figure 1.

An acceleration of dissolution rate ("Phase 3") after the plateau region of "Phase 2" has been reported in long-term static tests on powdered glass, using protocols similar to Product Consistency Test-B (PCT-B) or Materials Characterization Center-3 (MCC-3) tests. The tests were conducted for a longer period than has been used in most other durability tests. Just as the "Phase 2 " region may not be universal for all glass compositions, uncertainty exists as to whether all glasses undergo a "Phase 3." 
Consideration of "Phase 3" test results, and their compositional dependence, form the main subject of the present report.

Assessing the relationship of various durability tests on the same composition inevitably leads to issues such as the influence of leachate $\mathrm{pH}$ and the influence of the glass surface area to solution volume ratio (SA/V). A consensus has not been reached on these issues within the technical community. The present survey includes data from a variety of tests performed for extended times. Further analysis and understanding of the impact of SA/V, $\mathrm{pH}$, etc., may show some of these data to be inadequate to address the issue at hand, but they are included here in an effort to provide a technical basis on which the accelerated rate phenomenon can be assessed.

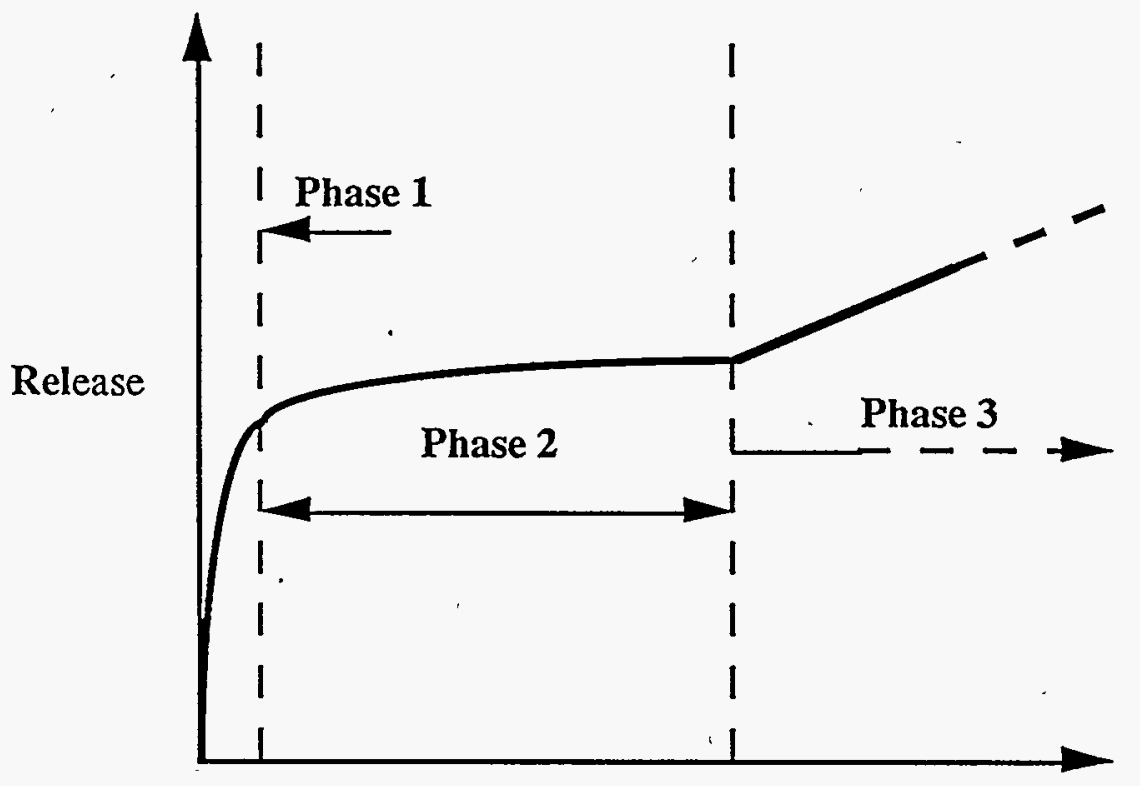

Time

Figure 1. Glass Dissolution Behavior (after Ebert, 1994)

Extensive discussion of the effect of test protocol on durability testing for waste glasses is contained in Ebert (1994). A brief summary of the impact of some of the test parameters follows.

\section{Effect of $S A / V$}

Corrosion of waste glasses proceeds extremely slowly--this is, of course, what makes them attractive as a wasteform. It is necessary to find legitimate ways to accelerate the corrosion process in order to make it amenable to laboratory study. One possible way to amplify the corrosion process is to increase SA/V, which is the ratio of the (corrodible) surface area of the glass to the volume of corrosive solution.

Ebert (1994) discusses the implications of the various ways to effect changes in SA/V. Crushed glass increases the surface area (SA) of a glass sample; however, the exact surface area is now much more difficult to determine than that of a monolithic sample. Different glasses, crushed to the same mesh size, may fracture into different characteristic shapes The same glass composition, crushed to different mesh sizes, may assume different characteristic shapes. Thus, mesh size is not perfectly correlated with surface area. The 
chemical reactivity of the fractured pieces may also be influenced by the presence or absence of sharp edges on these characteristic shapes, which confounds the results of leaching tests. Surface energy becomes important as the particle size diminishes; this could also influence the test results. Valid SA/V comparisons can be obtained for the same glass composition if the same mesh size is used and the SA/V is altered by altering the volume of leaching solution, $V$. This will be true down to some volume $V_{\min }$ below which the mechanism of the leachant interactions with the glass changes, e.g., at monolayer thicknesses of leaching solution.

Vapor hydration tests take the approach of decreasing $\mathrm{V}$ to its lower limit by subjecting the glass surface, not to bulk water, but to steam or vapor which may or may not be sufficient to condense. Because of the varying amount of vapor which contacts the glass surface, SA/ $V$ varies over the course of the test, from essentially infinity down to about $3000 \mathrm{~m}^{-1}$ (where the lower limit is estimated based on assumptions about the amount of water which can condense before liquid drips off the sample).

The parameter $S A /{ }^{*} t$ (where $t$ is the test duration) has been used to correlate data from tests having different SA/V values; theoretical justification for this parameter is based on a model in which saturation is the the controlling mechanism (Machiels and Pescatore, 1983). While this parameter is somewhat successful in collapsing the data from various experiments, discrepancies have been noted. The discrepancies are most apparent at the highest values of SA/V being compared, and occur even when the glass grain size has been kept constant (thus avoiding fracturing differences noted above). As noted previously, different "saturation" rates of corrosion have been observed for the same glass at different SA/V (Vernaz et al., 1990).

\section{Effect of $p H$}

A confounded effect on static test results is that of leachate pH. Tests at high SAVN, in which the initial ion exchange process occurs more quickly, typically show a higher $\mathrm{pH}$, since more alkali cations have been exchanged for hydrogen ions. Therefore, the leaching environment of the glass in a low SA/V test differs from that of a high SA/V test, and the glass will follow a different reaction path at high SA/V than at low values. This phenomenon has been offered as explanation of the deviation of results at high SA/V when correlated against SA/V*t. Bourcier et al. (1993) suggest that, due to this ion exchange effect, waste glasses may begin to scale poorly at SA $N$ ratios above 100 to $1000 \mathrm{~m}^{-1}$; this is below the SA/V of $2000 \mathrm{~m}^{-1}$ specified in the widely-used PCT protocol. They suggest . external control of $\mathrm{pH}$ during testing, or use of pre-reacted glasses which have already formed steady state surface alteration layers. Feng and Pegg (1994) have also advocated incorporation of a pH correction in models of dissolution.

\section{Effect of Temperature}

Another way to accelerate the corrosion process is to increase the rate of reaction by elevating the test temperature. The PCT is typically conducted at $90^{\circ} \mathrm{C}$. This temperature is fairly representative of the high-level waste glass temperature during at least some portion of the its interment in the repository (the temperature elevation above ambient ground temperatures is due to the decay of the immobilized radioactive species). Vapor hydration tests are conducted at temperatures up to $250^{\circ} \mathrm{C}$. Opinions differ as to the importance of the known temperature dependence of the secondary phase morphology. The secondary phases formed at high temperature are typically more ordered and less hydrous than those 
formed at lower temperature; the different phases have similar bond types and chemistry, however (Bourcier, 1995). This may imply that the same underlying reaction mechanisms are responsible for their formation.

The rate of hydration of glass in a vapor environment was found by Abrajano et al. (1986) to be lower than the corresponding rate in a hydrothermal test, while the rate of alteration product formation is higher in the vapor environment than in the hydrothermal. ${ }^{1}$ These conclusions were drawn from a study on several candidate waste glasses including SRL 211 and SRL 131, both of which have relatively high $\mathrm{Na}_{2} \mathrm{O}$ content (15.2 and 13.7 weight percent, respectively). In some of the comparisons, the temperature was the same in both the vapor and hydrothermal tests, while in others, the vapor hydration test was at higher temperature. The confounding of pressure effects was not assessed. Again, the $\mathrm{pH}$ was implicated as an underlying cause; a higher surface $\mathrm{pH}$ develops in the glass/vapor interaction, which in turn inhibits ion exchange and enhances network hydrolysis.

Temperature effects for a given corrosion mechanism have been shown to be well correlated by an Arrhenius form, i.e., the logarithm of the corrosion rate is proportional to $\mathrm{T}^{-1}$. This relationship holds provided the corrosion mechanism does not change over the temperature range; a change in mechanism is an inherent problem with the use of temperature to accelerate the corrosion process (Cunnane, 1994). In comparing, say, a vapor hydration test to an $\mathrm{MCC}-1$ test, both temperature and SA/V (and possibly pH) must be accounted for in the reaction progress parameter. To date, such data have not generally been presented in a form amenable to cross-comparison.

\section{DATA REVIEW}

Accelerated corrosion rates at long test times have been observed for glass compositions characteristic of high-level waste glass. The present report compiles observations of this behavior which have been reported in the literature, as well as data which may be relevant for analyzing the phenomenon. The data to be discussed are summarized in Table 1. Weight percent compositions of these glasses are given in Appendix 1.

\section{SRL 131. SRL 202 [Ebert and Bates. (1993), Ebert et al.. (1993)]}

Extended PCT-type tests were performed on both SRL 131 and SRL 202 glass. SRL 131 is a composition developed at the Savannah River Site (SRS) and is somewhat similar to the Environmental Assessment (EA) glass; SRL 202 is a composition more representative of glass to be produced in the Defense Waste Processing Facility (DWPF) at the SRS. SRL 131 has the higher $\mathrm{Na}_{2} \mathrm{O}$ content, which makes it of greater interest with respect to Hanford LLW glass compositions which will be high in sodium. Both of these compositions were actinide-doped, with both doped and undoped samples subjected to testing. The undoped samples were referred to as SRL 131U and SRL 202U, while the actinide-doped samples were referred to as SRL 131A and SRL 202A. The grain size of the powdered glass was kept constant (between 74 and $149 \mu \mathrm{m}$, which is PCT protocol) and the solution volume varied to achieve a variation of SA/V. The leaching solution was EJ-13, i.e., J-13 groundwater equilibrated with tuff. The resulting solution is relatively high in sodium and silicon ( 54 and $46 \mathrm{ppm}$, respectively) with a $\mathrm{pH}$ of 8.2 .

1 Note that Ebert and Bates (1990) reported data in which the rate of glass hydration was much higher in vapor tests than in hydrothermal tests. 
Table 1. Data Sources

\begin{tabular}{|c|c|c|c|c|}
\hline Glass ID & Test Type & $\begin{array}{l}\text { Test } \\
\text { Duration }\end{array}$ & $\mathrm{SA} / \mathrm{V}\left[\mathrm{m}^{-1}\right]$ & Reference \\
\hline $\begin{array}{l}\text { SRL } 131 \\
\text { SRL } 202\end{array}$ & $\begin{array}{l}\text { MCC-1 and } \\
\text { PCT-B }\end{array}$ & 1 year & $\begin{array}{l}10,340 \\
2000,20000\end{array}$ & $\begin{array}{l}\text { Ebert and Bates } \\
\text { (1993); Ebert et } \\
\text { al. (1993) } \\
\end{array}$ \\
\hline $\begin{array}{l}\text { SRL 200S } \\
\text { SRL 200R }\end{array}$ & Similar to PCT & $\begin{array}{l}\text { up to } 590 \\
\text { days }\end{array}$ & $\begin{array}{l}340,2000 \\
20000\end{array}$ & $\begin{array}{l}\text { Feng et al. } \\
\text { (1993) }\end{array}$ \\
\hline $\begin{array}{l}\text { WVCM40 } \\
\text { WVCMS0 } \\
\text { SRL 165U } \\
\text { SRL 202U } \\
\end{array}$ & Vapor hydration & up to 80 days & 4000 & $\begin{array}{l}\text { Ebert and Bates } \\
\text { (1990) }\end{array}$ \\
\hline $\begin{array}{l}\text { SAN60 } \\
\text { SM58 }\end{array}$ & $\begin{array}{l}\text { MCC- } 1 \text { and } \\
\text { variants }\end{array}$ & $\begin{array}{l}1 \text { year to } 3 \\
\text { years }\end{array}$ & $\begin{array}{l}10,100 \\
7000,7800\end{array}$ & $\begin{array}{l}\text { Van Iseghem } \\
\text { and Grambow } \\
\text { (1988); Patyn et } \\
\text { al. (1990) } \\
\end{array}$ \\
\hline MCC 76-68 & $\begin{array}{l}\text { Similar to } \\
\text { MCC- } 3 \text { or PCT }\end{array}$ & 1 year & $\begin{array}{l}670,1780 \\
>4540\end{array}$ & $\begin{array}{l}\text { Shade and } \\
\text { Strachan (1986) }\end{array}$ \\
\hline $\begin{array}{l}\mathrm{Na}_{2} \mathrm{O}_{-} \mathrm{B}_{2} \mathrm{O}_{3}-\mathrm{SiO}_{2}- \\
\mathrm{Al}_{2} \mathrm{O}_{3}-\mathrm{Fe}_{2} \mathrm{O}_{3}-\mathrm{CaO} \\
\text { System }\end{array}$ & PCT & 26 weeks & 2000 & Ramsey (1995) \\
\hline $\begin{array}{l}\text { SF6 } \\
\text { SF10 } \\
\text { WVCM47 } \\
\text { WVCM50 } \\
\text { WVCM59 } \\
\text { SRL131 } \\
\text { HW39 } \\
\end{array}$ & MCC-3 & up to 1 year & $10-40000$ & $\begin{array}{l}\text { Feng et al. } \\
(1990)\end{array}$ \\
\hline R7T7 & MCC-1 & 364 days & 500 & $\begin{array}{l}\text { Fillet et al. } \\
\text { (1986) }\end{array}$ \\
\hline R7T7 & Hydrothermal & 364 days & $\begin{array}{l}50 \text { (initial } \\
\text { value) }\end{array}$ & $\begin{array}{l}\text { Caurel et al. } \\
(1990)\end{array}$ \\
\hline $\mathrm{R} 7 \mathrm{T7}$ & $\begin{array}{l}\text { Monolith and } \\
\text { powder tests }\end{array}$ & 365 days & $\begin{array}{l}400 \\
2000 \\
8000 \\
20000 \\
\end{array}$ & $\begin{array}{l}\text { Vernaz et al. } \\
(1990)\end{array}$ \\
\hline $\begin{array}{l}\text { Multicomponent } \\
\text { borosilicate (similar to } \\
\text { West Valley glass) }\end{array}$ & $\begin{array}{l}\text { Partial } \\
\text { replenishment }\end{array}$ & $\begin{array}{l}1 \text { year and } 4 \\
\text { years }\end{array}$ & 970,1940 & $\begin{array}{l}\text { Barkatt et al. } \\
\text { (1991) }\end{array}$ \\
\hline
\end{tabular}


Of the tests in this series, SRL131A showed a rate acceleration at $S A V=2000 \mathrm{~m}^{-1}$, while SRL 202A and SRL 202U showed a rate acceleration at SA $/ V=20000 \mathrm{~m}^{-1}$. The rate acceleration for the SRL 131A glass occurred slightly earlier in time, at about 140 days vs. 182 days for the SRL 202 glasses. A rate acceleration was not observed for any of the samples under the other test conditions.

The behavior of the SRL 202A glass has been further discussed in Ebert et al. (1993). Sudden increases in solution concentrations of boron, sodium, and potassium were observed at about 182 days, with continued releases at accelerated (non-stoichiometric) rates for the subsequent period up through two years. The boron release was the most accelerated. The solution concentrations of silicon and othér components increased only slightly at 182 days, and were nearly constant throughout the remaining test period. Figure 2 , reproduced from Ebert et al. (1993) shows these results.

$$
\begin{aligned}
& i=\text { Lithium } \quad i=\text { Boron } \quad i=0 \text { Silicon } \\
& \text { ^ Sodium } \downarrow \text { Potassium } \text { Uranium }
\end{aligned}
$$
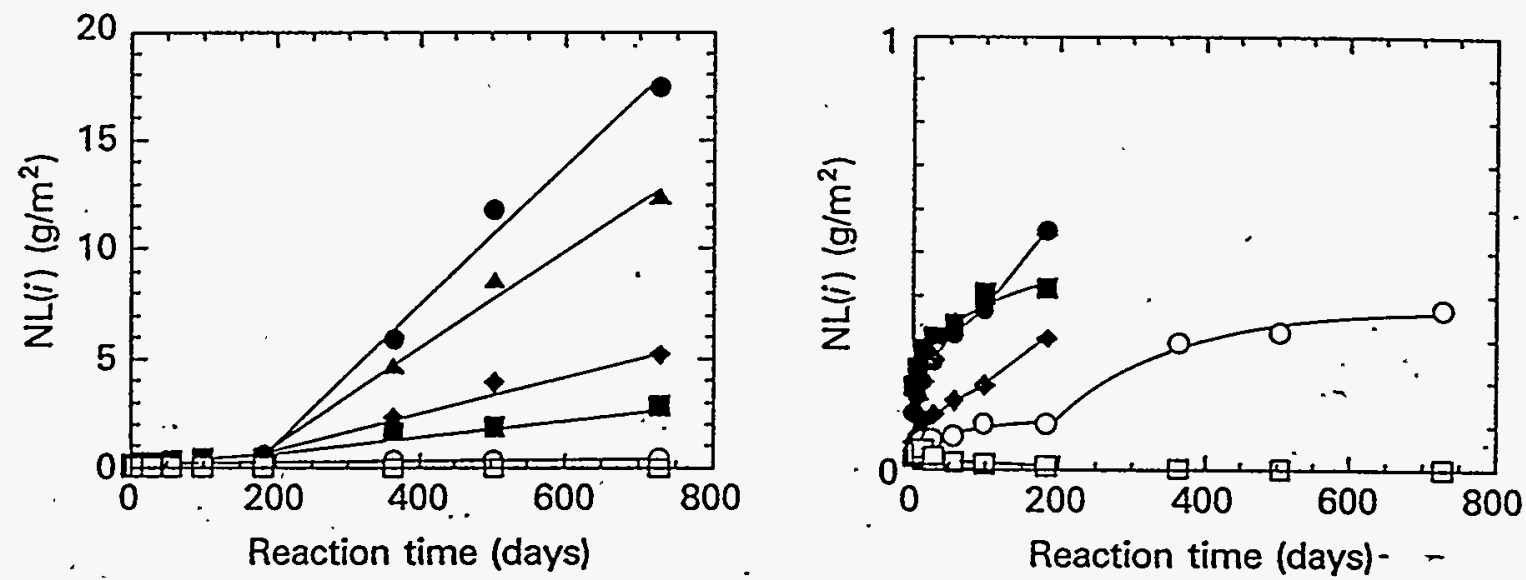

Figure 2. Corrosion behavior of SRL $202 \mathrm{~A}$ glass at $\mathrm{SA} / \mathrm{V}=20000 \mathrm{~m}^{-1}$ (reproduced from Ebert et al., 1993)

The hypothesis of Ebert et al. (1993) was that the acceleration in corrosion rate occurred upon the formation of a secondary phase other than clay. While clay formed in the reaction layer at all reaction times, clinoptilolite and amorphous silicon were seen at the surface only after the increase in release rate. Ebert et al. speculated that these phases accelerate the rate by consuming silicon and lowering the concentration of non-dissociated silicic acid.

The behavior of SRL 202 U was qualitatively similar to that of SRL 202A, showing an upturn in corrosion rate for boron, sodium, and potassium at about 182 days. However, the magnitudes of the elevated releases in SRL 202U at the end of one year were smaller by 
a factor of two than those of SRL 202A. This is in contrast to the results of Feng et al. (1993), who found that a simulated waste glass leached faster than the corresponding radioactive glass by a factor of 40 within one year. The results of the latter study will be discussed in the next section of this report.

SRL 131A showed an acceleration in the releases of boron and the alkalis only at $2000 \mathrm{~m}^{-1}$. These results, taken from Ebert et al. (1993) are shown in Figure 3. The acceleration was not seen at the higher $S A / V$ ratio. ${ }^{2}$ This is significant in several respects. First, $S A / V *_{t}$ to some extent represents a reaction progress parameter. Few durability tests have been conducted at the high $S A / V^{*}$ value $\left(3.64 \times 10^{6}\right.$ days $\left./ \mathrm{m}\right)$ associated with the rate change for the SRL 202 glasses. The occurrance of the acceleration phenomenon only at high SA/V*t values could imply that the extensive MCC-1 and PCT databases which have been assembled are inconclusive because the process was not allowed to proceed far enough. The occurrance of the acceleration in the SRL 131A glass at SA/V $=2000 \mathrm{~m}^{-1}$ and SA/V $*_{\mathrm{t}}$ $=2.8 \times 10^{5}$ days $/ \mathrm{m}$ is within the range of at least some of the other tests which have been performed. The behavior of SRL 131A glass at a widely used SAN value implies that these other data may have relevance to the present discussion, and that not all glasses necessarily show accelerated behavior at long times.

$$
\begin{aligned}
& i=\text { Lithium } \quad i=\bullet \text { Boron } \quad i=0 \text { Silicon } \\
& \text { - Sodium }+ \text { Potassium } \text { Q Uranium }
\end{aligned}
$$

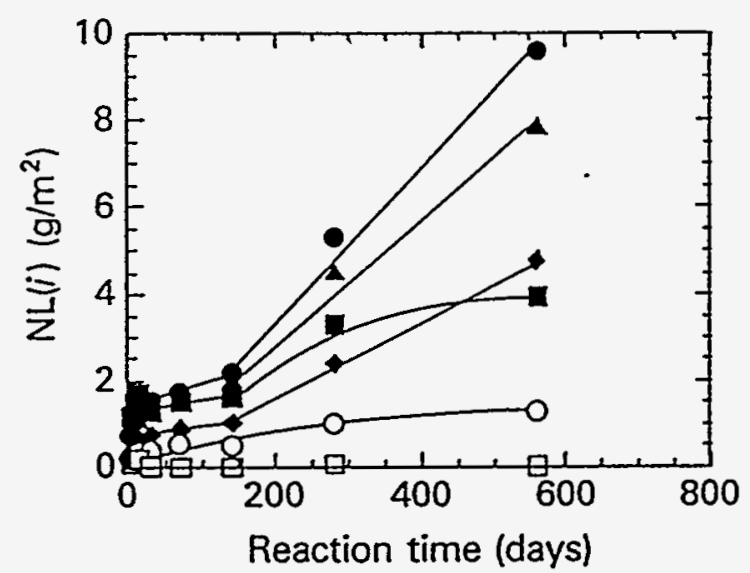

Figure 3. Corrosion behavior of SRL 131A glass at $\mathrm{SA} / \mathrm{V}=2000 \mathrm{~m}^{-1}$ (reproduced from Ebert et al., 1993)

The absence of acceleration at $2.8 \times 10^{5}$ days $/ \mathrm{m}$ for the higher SA/V test of SRL 131A glass appears to highlight the shortcomings of $S A /{ }^{*} t$ as a universal reaction parameter. This,

2 Although Ebert and Bates (1993) state that the same behavior was observed for SRL 131A at SAN = $20000 \mathrm{~m}^{-1}$, the published figure shows only a possible slight upturn in lithium release; there is some ambiguity as to whether the increase actually represents a slope change. 
however, contradicts the results of Feng et al. (1990), who found that $S A / V^{*} t$ was a valid scaling parameter for the SRL 131 composition (those results are discussed below). The observation of acceleration at $\mathrm{SA} / \mathrm{V}=2000 \mathrm{~m}^{-1}$ obviates the concern that the acceleration is somehow an artifact of the high SA/V associated with some of the other accelerated corrosion data.

\section{SRL 165. SRL 131. and SRL 200 Glasses (Feng et al. 1993)}

Long-term (up to 720 days) PCT and MCC tests were conducted on SRL 165, 131, and 200 type glasses, both simulated (denoted SRL 165S, etc.) and radioactive (denoted SRL 165R, etc.) by Feng et al. (1993). The focus of the research was on the differences between radioactive and simulated glasses of the same bulk composition. All of the glass compositions were tested at $\mathrm{SA} / \mathrm{V}=340 \mathrm{~m}^{-1}$ (monolith tests) and $2000 \mathrm{~m}^{-1}$ (powder tests). The SRL 200-type glasses were also tested at $S A / \mathrm{V}=20000 \mathrm{~m}^{-1}$. The leaching solution was EJ-13 water; particle size in the PCT-type tests were between 74 and $149 \mu \mathrm{m}$.

The results of the SRL 131R test at $2000 \mathrm{~m}^{-1}$ should be comparable to the results of Ebert and Bates for the glass denoted SRL 131A, since the particle size, SA/V ratio, test temperature, and test duration are the same for both cases. Figure 4 shows the data from Feng et al (1993) which can be compared to Figure 3 showing the data of Ebert et al. (1993). The results are quite different, however. The results of Feng et al. show no acceleration in release throughout the test period of about 280 days, whereas the acceleration shown in the data of Ebert et al. occurred at about 140 days. Moreover, the releases of the Feng et al. SRL 131R glass are much lower than those of the Ebert et al. SRL 131A glass, even for the period prior to the acceleration in the Ebert et al. experiment.
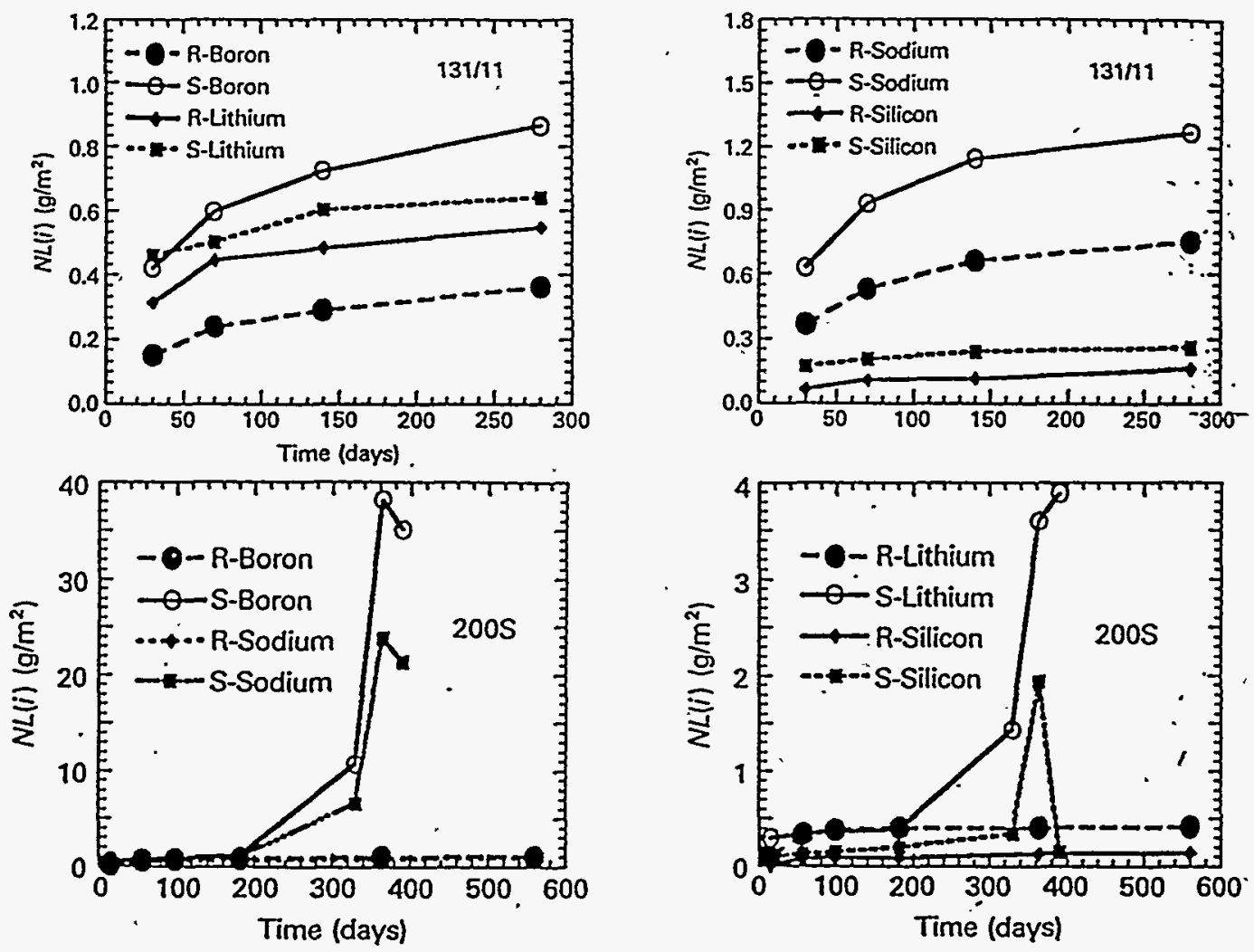

Figure 4. Corrosion behavior of SRL $131 R / S$ glasses at $2000 \mathrm{~m}^{-1}$ and SRL $200 \mathrm{R} / \mathrm{S}$ glasses at $20000 \mathrm{~m}^{-1}$ (reproduced from Feng et al., 1993) 
Comparison of the two glass compositions (Appendix 1) shows that considerable compositional differences exist between these two glasses, both of which are nominally SRL 131 glass. The Ebert et al. SRL 131A glass, which showed an accelerated rate, is low in $\mathrm{Al}_{2} \mathrm{O}_{3}$, high in $\mathrm{Fe}_{2} \mathrm{O}_{3}$, high in $\mathrm{K}_{2} \mathrm{O}$, and low in $\mathrm{Na}_{2} \mathrm{O}$ with respect to the Feng et al. SRL $131 \mathrm{R}$ glass composition. The lower $\mathrm{Al}_{2} \mathrm{O}_{3}$ in the glass showing an accelerated rate is of particular interest in view of the conclusions of some researchers (discussed below) that high-aluminum glasses, while showing improved durability in a short-term test, are less durable in long-term tests.

Accelerated leaching was not observed in the SRL 165R/S glasses of Feng et al. (1993) These compositions are also lower in $\mathrm{Al}_{2} \mathrm{O}_{3}$ and higher in $\mathrm{Fe}_{2} \mathrm{O}_{3}$, with respect to the SRL $131 \mathrm{~A}$ glass of Ebert et al., but have comparable amounts of $\mathrm{Na} 2 \mathrm{O}$. They are considerably higher in $\mathrm{SiO}_{2}$.

Accelerated leaching was observed in the SRL 200 S glass tested by Feng et al. (1993) at a $\mathrm{SA} / \mathrm{V}=20000 \mathrm{~m}^{-1}$. It was not observed in the SRL 200R glass. The results are shown in Figure 4. Boron, sodium, and lithium rise after 182 days, followed by a spike between 330 and 390 days which was associated with a $\mathrm{pH}>12$. The time at which acceleration occurred was the same as the Ebert et al. SRL 202 glasses, but the details of the acceleration are somewhat different, as can be seen by comparing Figures 2 and 4 . Ebert et al.'s SRL 202-type glasses show a constant, higher release rate rather than the spike behavior. Of note is that the final release values of Feng et al.'s SRL 200 S glass at 390 days are lower than the preceding values at 330 days for boron and sodium; the rate of increase slows considerably for lithium. Finally, the silicon behavior for this glass is a true spike; the normalized release decreases to pre-acceleration levels by 390 days. A final pH value at 390 days was not reported in Feng et al. (1993).

Compositionally, the SRL 200R/S glasses of Feng et al. (1993) are slightly higher in $\mathrm{Al}_{2} \mathrm{O}_{3}$ and $\mathrm{B}_{2} \mathrm{O}_{3}$ and lower in $\mathrm{Fe}_{2} \mathrm{O}_{3}, \mathrm{Na}_{2} \mathrm{O}$, and $\mathrm{SiO}_{2}$ than the SRL 202 glasses of Ebert et al. (1993). Since one of these two glasses remained stable, one could postulate that Feng et al.'s SRL 200 composition is slightly more stable than the SRL 202 composition used by Ebert et al. The combination of higher $\mathrm{Al}_{2} \mathrm{O}_{3}$ and lower $\mathrm{Fe}_{2} \mathrm{O}_{3}$ for the more stable glass is similar to the comparison noted above between the two versions of SRL 131 glass.

As noted above, the radioactive glasses of Feng et al. (1993) always showed lower leach rates than the corresponding simulated glasses, a fact attributed by the researchers to the lowered $\mathrm{pH}$ induced by radiolytic acid formation. This observation was also considered in explaining the absence of an acceleration for the radioactive SRL 200 glass. The $\mathrm{pH}$ of SRL 200S glass (which showed an acceleration) was 11.82 prior to the excursion, as opposed to 11.65 for the SRL 200R glass which remained stable. No pH excursion was associated with the leach acceleration in the glasses studied by Ebert et al. (1993), however. As with the Ebert et al. work, clinoptilolite was observed on the surface of Feng et al.'s glass SRL 200S (possibly transforming into potassium feldspar).

\section{Vapor Hydration Tests of West Valley and Savannah River Glasses (Ebert and Bates. 1990)}

Vapor hydration tests were performed at $200^{\circ} \mathrm{C}$ on WVCM40 and WVCM50, similar to the West Valley ceramic melter waste glass compositions, and on SRL 165 and SRL 202. As shown in Appendix 1, all of these glasses have $\mathrm{Na}_{2} \mathrm{O}$ content below that of interest for Hanford LLW glass compositions. . A limitations in interpreting the results of vapor hydration tests is the variation in and estimation of SA/V. SA/V was estimated to be $3 \times 10^{8}$ 
$\mathrm{m}^{-1}$ at the beginning of the test (based on sorption isotherm measurements), down to 4000 $\mathrm{m}^{-1}$ by the end of the test. The latter value was dictated by assuming the limit of all . available water is condensed on the sample, except for that required to maintain saturated vapor.

Another problem in interpreting these tests is the lack of available solution for leachate analysis. In lieu of leachate analysis, the variation of alteration depth with time was used as a measure of reaction rate. An instantaneously high reaction rate and subsequent saturation with respect to silica is assumed to occur as the first small amount of vapor contacts the sample. For three of the four glasses, the depth was negligible for several days (implying that the initial rate falls to a subsequent, very low reaction rate); SRL 165 did not show this low rate of reaction, however. Reaction rate then increases to a higher, constant rate (as inferred from the time-dependence of the alteration layer depth), although this is dependent on the ability of precipitates to form, reducing the ion concentrations in solution.

The relationships between reaction rate and alteration layer depth, and between test duration at vapor hydration conditions versus hydrothermal conditions, are not quantified by the researchers. Presumably, the initial reaction rate, not obtainable from this type of test, corresponds to Phase 1 of Figure 1; the low reaction rates which occur over the first few days (beyond the initial reaction rate) corresponds to the Phase 2 plateau of Figure 1 . It is not clear why SRL 165 glass did not show this phase of behavior. Its continuous high rate of alteration layer depth increase would suggest that it does not have a plateau phase, although the results of Feng et al. (1993) discussed above imply otherwise. The time dependence of the alteration layer growth is associated with Phase 3 of Figure 1.

\section{SAN60. SM58 Glasses [Van Iseghem and Grambow (1988), Patyn et al., (1990)]}

These two glass compositions were tested in distilled water at $90^{\circ} \mathrm{C}$ by Van Iseghem and Grambow (1988). The samples were at $S A / V=10 \mathrm{~m}^{-1}$ (monolith) and at $S A / V=100$ and $7800 \mathrm{~m}^{-1}$ (powdered glass). Using the GLASSOL computer code, Van Iseghem and Grambow predicted that the reaction rate for SAN60 would accelerate after a period of leaching under saturated conditions; the acceleration would occur as soon as sodium and aluminum had reached the solubility limit for analcime. This was predicted to occur after 30 years for the $S A / V=10 \mathrm{~m}^{-1}$ case and after 3 years for the $S A / V=100 \mathrm{~m}^{-1}$ case. In the $\mathrm{SA} / \mathrm{V}=100 \mathrm{~m}^{-1}$ case, SAN60 showed a continuous, gradual increase in leach concentration during the three-year test period. An acceleration was observed in the $\overline{7} 800$ $\mathrm{m}^{-1}$ test at about 100 days. Although analcime was found to form on both glasses, the higher aluminum content of the SAN60 glass was thought to be responsible for the acceleration. That is, in the case of SM58, when analcime forms, there is sufficient silicon leached into solution to combine with the aluminum, also in solution. For SAN60, however, there is insufficient silicon in solution to combine with the higher levels of aluminum present in solution, so the silicon content of the surface layer redissolves to feed analcime formation. These authors concluded from their results that high aluminum content, while promoting short term durability, was detrimental to long-term durability. Obviously, these conclusions depend on the stability diagrams of the glass compositions in question.

The researchers' parametric study of stability fields, which led to these conclusions, provided not only an explanation for the corrosion acceleration of SAN60, but also a basis for predicting the continued stability of SM58. This is important in determining the compositional constraints on long-term accelerated corrosion. 
A related study of these glasses was conducted by Patyn et al. (1990). The static leach tests were conducted at $90^{\circ} \mathrm{C}$ and $120^{\circ} \mathrm{C}$, at $\mathrm{SA} / \mathrm{V}=7000 \mathrm{~m}^{-1}$. The acceleration observed for SAN60 in the previous study was not observed in this study for either glass at $90^{\circ} \mathrm{C}$. A continued corrosion was observed at $90^{\circ} \mathrm{C}$ for SAN60. An acceleration was observed in the $120^{\circ} \mathrm{C}$ test for SAN60, with a jump in the final leach values for SM58 indicating a possible acceleration in this glass as well. The researchers found that the smaller glass particles had completely dissolved by this time, thus lowering the SA/V ratio, but did not relate this observation to the acceleration.

The acceleration in SAN60 rate at $120^{\circ} \mathrm{C}$ was not reproduced by the GLASSOL code. Unfortunately, no modeling of the SM58 results was reported. This is important in that the previous work appeared to establish a criterion for determining that this glass would be stable. The final jump in release values appears to contradict the previous modeling results.

\section{76-68 Glass (Shade and Strachan. 1986)}

Leach tests were conducted on powdered samples of this glass for periods up to one year. The highest SA $N$ was not definitively determined; the sample consisted of ground glass passing through -325 mesh (i.e., particle diameters less than $44 \mu \mathrm{m}$ ). This corresponds to a minimum SA/V of $4540 \mathrm{~m}^{-1}$. This glass sample was found to have completely hydrolyzed after 90 days, so the interpretation of results is not clear. The other samples were performed at $\mathrm{SA} / \mathrm{V}=670$ and $1780 \mathrm{~m}^{-1}$, at $90^{\circ}$ and $150^{\circ} \mathrm{C}$. Deionized water and a dilute sodium bicarbonate silicate solution (synthetic groundwater) were both used as leaching solutions.

Dissolved silicon reached saturation in these tests, while boron and colloidal silicon increased at a constant rate. These species were associated with iron, zinc, and possibly uranium. The concentration of uranium in the filtrates increased dramatically after about 260 days. The relatively low SA/V of the tests for which unhydrolyzed glass remained, and the variation of grain size, make these results somewhat inconclusive with regards to the possibility of accelerated corrosion for this glass composition.

\section{$\mathrm{Na}_{2} \mathrm{O}-\mathrm{B}_{2} \mathrm{O}_{2}-\mathrm{SiO}_{2}-\mathrm{Al}_{2} \mathrm{O}_{2}-\mathrm{Fe}_{2} \mathrm{O}_{2}-\mathrm{CaO}$ System (Ramsey, 1995)}

A series of 30 glasses in the $\mathrm{Na} 2 \mathrm{O}-\mathrm{B}_{2} \mathrm{O}_{3}-\mathrm{SiO}_{2}-\mathrm{Al}_{2} \mathrm{O}_{3}-\mathrm{Fe}_{2} \mathrm{O}_{3}-\mathrm{CaO}$ system were subjected to the PCT for periods of one, two, four, and 26 weeks, and to the MCC-1 test for four and 24 weeks (Ramsey, 1995). The test matrix was designed as a parametric study of high level waste borosilicate glass. The matrix called for 33 compositions, of which only 30 formed glass. The compositions of the 30 glasses are given in Appendix 1. Most have a $\mathrm{Na}_{2} \mathrm{O}$ content in the range of interest for Hanford LLW glass.

PCT protocol was used for the ground glass tests, which were performed at $90^{\circ} \mathrm{C}$, with 74 $149 \mu \mathrm{m}$ sized particles for an estimated SA $/ \mathrm{V}=2000 \mathrm{~m}^{-1}$; deionized water was used as the leaching solution. MCC-1 tests were performed at $90^{\circ} \mathrm{C}$ with deionized water, using monoliths with $10 \mathrm{ml} / \mathrm{cm}^{2}$ of measured glass surface. Normalized releases were reported for silicon, boron, and sodium. Since the MCC-1 tests' reaction progress was less than that of the PCT (due to lower SA/V), only the PCT results will be discussed here.

No leach rate excursions were observed in these tests. In general, the glasses fell into one of several groups: 
- Glasses which completely dissolved (usually within the first two weeks of the test period)

- Glasses in which the silicon release approached steady state, while sodium and boron releases continued to increase

- Glasses in which all three constituents continued to be released.

Examples of the latter two types of behavior are shown in Figures 5 and 6 . Table 2 shows which category each of the glasses fell into. The glasses which dissolved during the test were characterized by low aluminum, low iron, high boron, and high sodium and/or calcium. Although there were exceptions, glasses for which silicon release approached steady state were characterized by either high aluminum and/or iron, combined with high sodium and/or calcium, or else by low aluminum/iron, combined with low sodium/calcium. High releases (but not complete dissolution) were characterized by high sodium combined with either high boron or low aluminum.

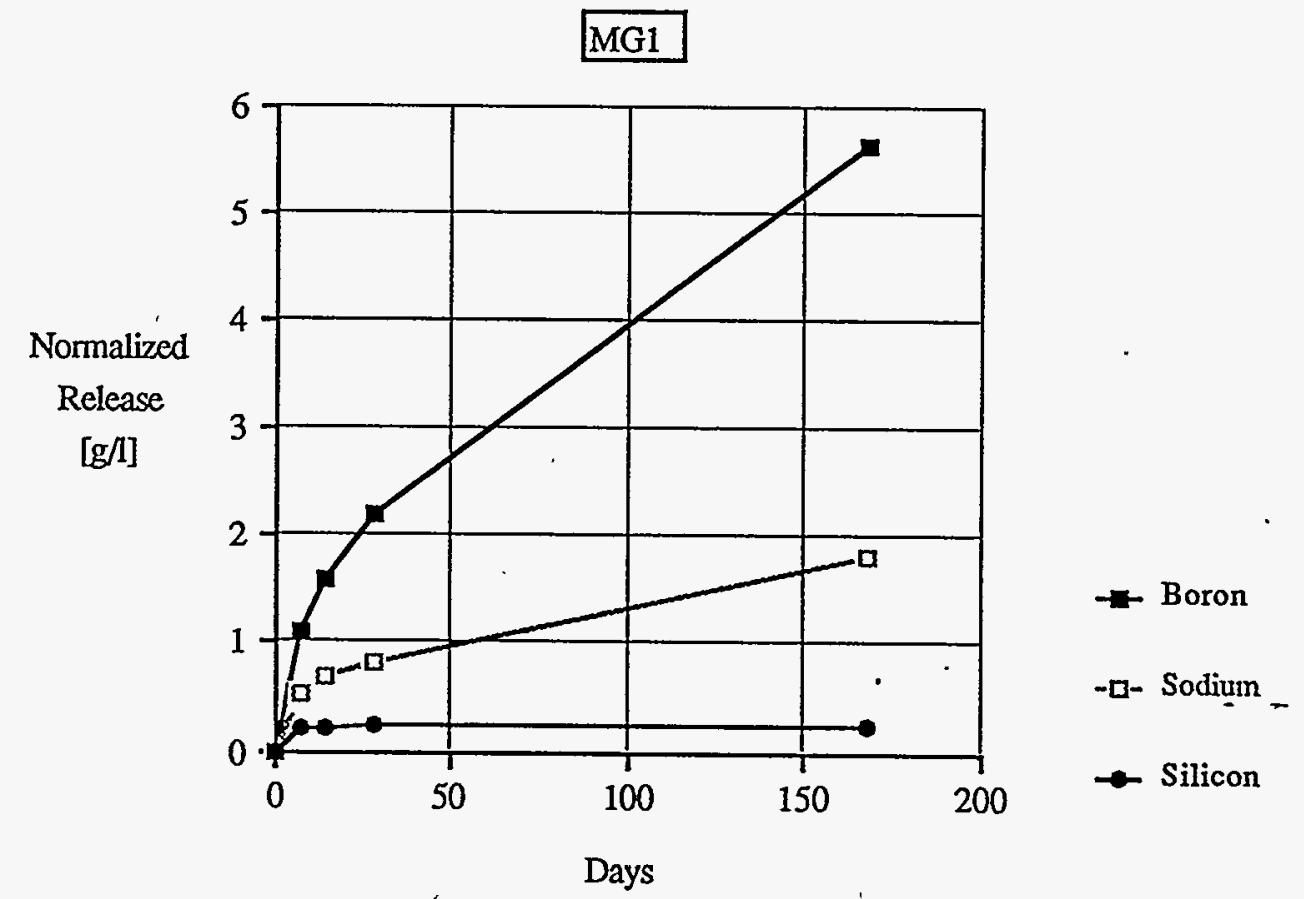

Figure 5. Corrosion behavior of glass MG1 (typical of glasses in which silicon release leveled off while boron and sodium releases continued). 


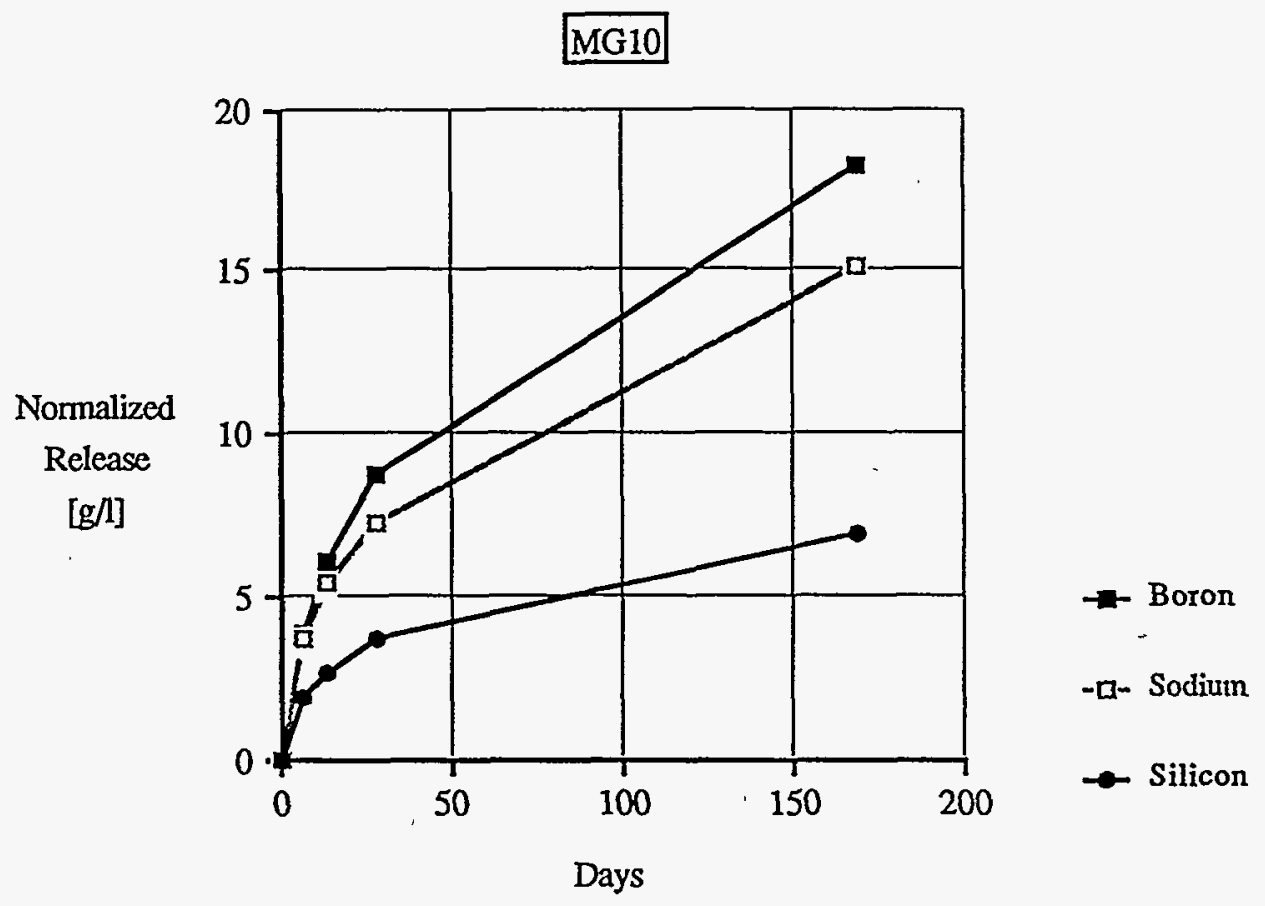

Figure 6. Corrosion behavior of glass MG10 (typical of glasses in which silicon, boron and sodium releases continued throughout the test period).

Table 2. Behavior of Glasses in $\mathrm{Na}_{2} \mathrm{O}-\mathrm{B}_{2} \mathrm{O}_{3}-\mathrm{SiO}_{2}-\mathrm{Al}_{2} \mathrm{O}_{3}-\mathrm{Fe}_{2} \mathrm{O}_{3}-\mathrm{CaO}$ System Study (Ramsey, 1995)

\begin{tabular}{|l|l|}
\hline Behavior & Glasses \\
\hline Silica steady state reached & MG1, MG4, MG5, MG6, MG8, MG11, \\
& MG13, MG19, MG24, MG25, MG26, \\
& MG27, MG28, MG29, MG30, MG315 \\
\hline Continued release of all species & MG2, MG10, MG15, MG16, MG17, \\
\hline Complete dissolution & MG20, MG21, MG22, MG23, MG32 \\
\hline
\end{tabular}

Of those glasses which did not completely dissolve during testing, glasses MG10, MG13, and MG19 had the highest releases.

These PCT's were run longer than the time at which the SRL 131A glass of Ebert et al. (1993) showed an acceleration at the same SA/V. Because of the lack of data between 28 and 182 days, the lack of evidence of excursion is somewhat inconclusive, although the trends as shown in the figures are consistent with a steady release of boron and sodium (and possibly silicon). Although these glasses are not waste glasses, it is of interest to compare the behavior of the compositions nearest the SRL 131A glass. The closest 
composition is probably MG24; the two glasses are compared in Table 3 for convenience. The leaching behavior of MG24 is shown in Figure 7.

Comparing Figure 7 with Figure 3, the silica saturation is reproduced. The sodium release is greater than the boron release for MG24, while the reverse is true for SRL 131A. Note that, for this SA/V value, multiplying the SRL $131 \mathrm{~A}$ releases (in $\mathrm{g} / \mathrm{m}^{2}$ ) by a factor of two should make them directly comparable to the $M G 24$ releases (in $\mathrm{g} / 1$ ). The silicon releases agree well, but the SRL 131A boron and sodium releases are higher than those of MG24, both before and after the acceleration observed in SRL 131A. While the lack of data from 28 to 180 days makes the determination of an accelerated rate (or lack thereof) inconclusive for MG24, its behavior seems consistent with a continued gradual release of boron and silicon over the test period.

Table 3. Compositions (in wt \%) of MG24 and SRL 131A

\begin{tabular}{|l|l|l|}
\hline Component & MG24 & SRL 131A \\
\hline $\mathrm{Al}_{2} \mathrm{O}_{3}$ & 7.415 & 3.27 \\
\hline $\mathrm{B}_{2} \mathrm{O}_{3}$ & 10.491 & 9.65 \\
\hline$\sum$ Alkaline Earth Oxides & 4.568 & 2.38 \\
\hline$\sum$ Alkali Oxides & 17.210 & 18.96 \\
\hline $\mathrm{Fe}_{2} \mathrm{O}_{3}$ & 12.241 & 12.7 \\
\hline $\mathrm{Cr}_{2} \mathrm{O}_{3}$ & & 0.13 \\
\hline $\mathrm{CuO}$ & & 0.02 \\
\hline $\mathrm{FeO}$ & 1.735 & \\
\hline $\mathrm{MnO}_{2}$ & & 2.43 \\
\hline $\mathrm{NiO}^{\mathrm{SOO}}$ & & 1.24 \\
\hline $\mathrm{SiO}$ & 46.339 & 43.8 \\
\hline
\end{tabular}




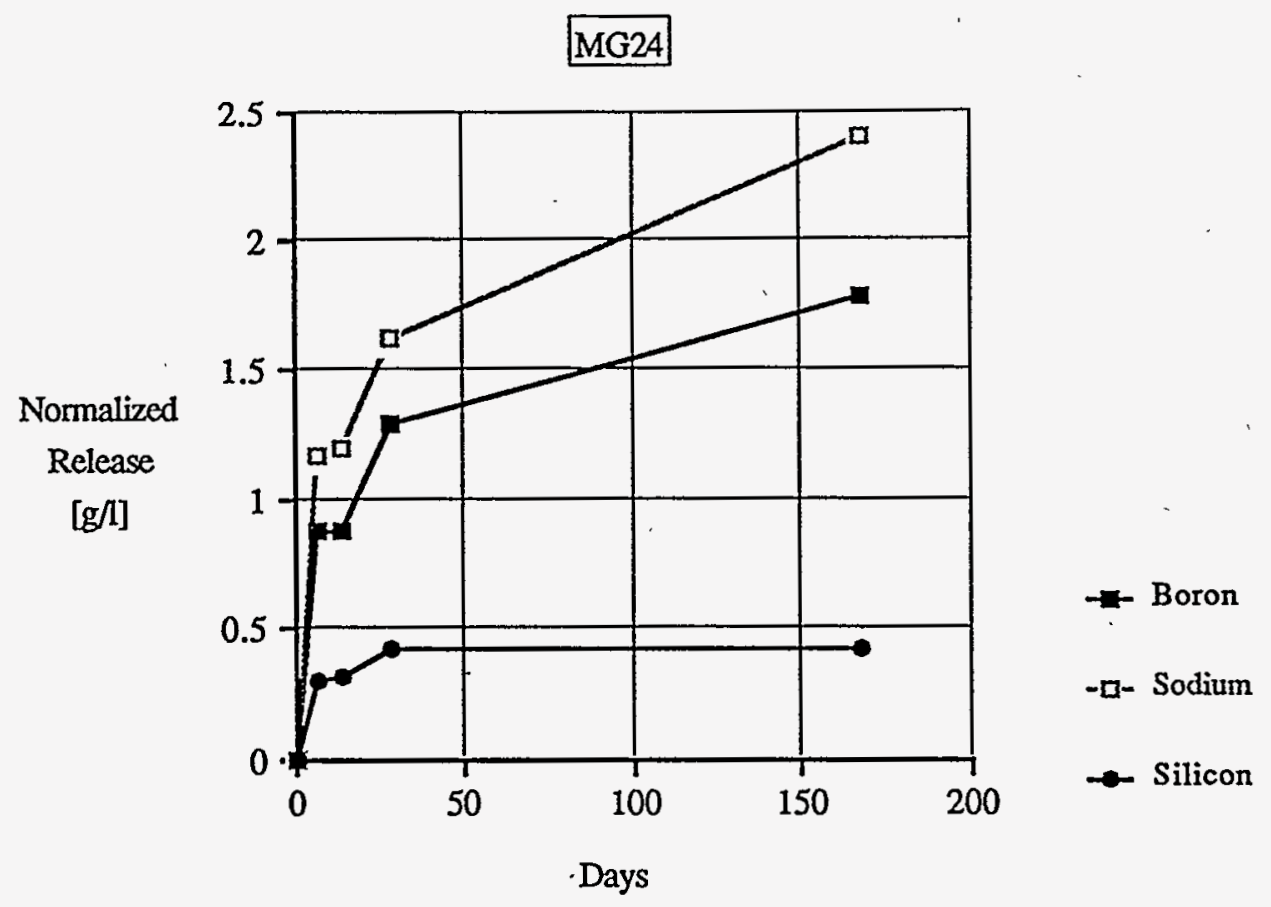

Figure 7. Corrosion behavior of glass MG24 (composition similar to SRL 131A)

West Valley, Hanford, and Savannah River Glasses (SF6. etc.) (Feng et al. 1990)

A durability study of several waste glass compositions was performed by Feng et al. (1990). The focus of the study was the effect of SA/V ratio and the viability of the SA/ $V *_{t}$ parameter. MCC-3 protocol was used in static leaching tests; the SA/V ratio was varied up to a maximum of $40000 \mathrm{~m}^{-1}$ by holding the particle size range constant (at 74-149 $\mu \mathrm{m}$ ) and varying the amount of glass and/or leaching solution. The volume of leaching solution was either 40 or $100 \mathrm{ml}$. One possible drawback to the test protocol was that four-ml samples were extracted at the specified sampling times; this perturbation represents a $10 \%$ variation in the 40-ml tests. The effect on $\mathrm{pH}$, hence on subsequent leaching behavior, of this procedure was not discussed in the original reference. Boron and silicon releases were reported as a function of $S A / V * t$ (log scale), with $S A / V$ as a parameter.

The authors of this study concluded that the viability of using SA/V*t scaling was composition-dependent. The study included data at'a higher SA/V ratio $\left(40000 \mathrm{~m}^{-1}\right)$ than any of the other studies identified; all of the glasses tested at this SA/V happened to be among those which did follow $S A / V * t$ scaling. The tests at $S A / V=40000 \mathrm{~m}^{-1}$ were conducted for only 56 days, however, so the maximum value of SA/V*t was about $2.2 \times 10^{6} \mathrm{day} / \mathrm{m}$. This is comparable to some of the other studies discussed in this report but is less than the value of SA/V*t of $3.64 \times 10^{6} \mathrm{day} / \mathrm{m}$ at which accelerated corrosion was observed in the SRL 202 glasses of Ebert et al. (1993).

One of the glasses tested was SRL 131A; it was shown to follow SA/ ${ }^{*}$ t scaling up to $\mathrm{SA} / \mathrm{V}=40000 \mathrm{~m}-1$. The maximum $\mathrm{SA} / \mathrm{V} * \mathrm{t}$ value of $2.2 \times 10^{6} \mathrm{day} / \mathrm{m}$ attained by Feng et al. (1990) exceeds that at which accelerated corrosion was observed by Ebert et al. (1993) in SRL 131A glass. No acceleration of corrosion was found by Feng et al. (1990) in the 
SRL 131 glass, however. This appears to contradict the observation of accelerated corrosion at $\mathrm{SA} / \mathrm{V}=2000 \mathrm{~m}^{-1}\left(\mathrm{SA} / \mathrm{V} * \mathrm{t}=2.8 \times 10^{6} \mathrm{day} / \mathrm{m}\right)$ by Ebert et al. (1993).

None of the glasses in this study appeared to have evidenced accelerated corrosion. A possible exception is glass WVCM59, a derivation of the original West Valley waste glass composition WV205 having a higher Al/Si oxide ratio than the latter. The use of a log scale for $S A / V^{*} t$ in the plots of the Feng et al. (1990) study makes the identification of a rate acceleration somewhat difficult, but the last boron release datum point for this glass clearly indicates a slope change. No comparable change is observable in the sodium data, however.

\section{RTT7 Glass [Fillet et al. (1986). Caurel et al.(1990). Vernaz et al. (1990)]}

A series of static leaching tests was performed on this glass by Fillet et al. (1986), using the $\mathrm{MCC}-1$ protocol at a SA/V ratio of $50 \mathrm{~m}^{-1}$. Six identical tests were performed to obtain a mean value of leach rate. Table 4, reproduced from the original reference, shows the results as a function of time. Although more or less constant concentrations of silicon and boron were obtained between 14 and 273 days for all six samples, one of the six showed a sharp increase in both silicon and boron concentrations at 364 days. This was regarded as spurious by the researchers. In a second series of tests on radioactive versions of the same composition, neither of the two samples tested beyond 273 days showed the acceleration behavior.

Table 4. Tabulated results of durability tests on R7T7 glass (reproduced from Fillet et al., 1986)

\begin{tabular}{|c|c|c|c|c|c|c|c|c|}
\hline \multirow{2}{*}{$\begin{array}{c}\text { Time } \\
\text { (days) }\end{array}$} & \multicolumn{8}{|c|}{ Concentrations in $\mathrm{mg} \cdot \mathrm{1}^{-1}$ (Values in Parentheses Are lor Boron) } \\
\hline & RTI-1 & $\mathrm{R} 7 \mathrm{TT \cdot 2}$ & ATT7-3 & $8777-4$ & RTT/5 & RTT7-6 & $\bar{x}$ & $\sigma$ \\
\hline 1 & $\begin{array}{l}8 \\
(1.42)\end{array}$ & $\begin{array}{c}3.8 \\
(0.65)\end{array}$ & $\begin{array}{c}6.8 \\
(1.05)\end{array}$ & $\begin{array}{l}12.3 \\
(1.65)\end{array}$ & $\begin{array}{c}7.8 \\
(1.25)\end{array}$ & $\begin{array}{l}10.3 \\
(0.95)\end{array}$ & $\begin{array}{c}8.2 \\
(1.20)\end{array}$ & $\begin{array}{c}2.9 \\
(0.3)\end{array}$ \\
\hline 3 & $\begin{array}{l}14.8 \\
(3.92)\end{array}$ & $\begin{array}{l}8.1 \\
(1.65)\end{array}$ & $\begin{array}{l}10.1 \\
(1.75)\end{array}$ & $\begin{array}{l}13.1 \\
(2.55)\end{array}$ & $\begin{array}{c}9.1 \\
(2.85)\end{array}$ & $\begin{array}{l}17.6 \\
(255)\end{array}$ & $\begin{array}{l}11.1 \\
(2.5)\end{array}$ & $\begin{array}{c}2.5 \\
(0.8)\end{array}$ \\
\hline 7 & $\begin{array}{l}17.8 \\
(4.62)\end{array}$ & $\begin{array}{l}16.0 \\
(2.6)\end{array}$ & $\begin{array}{l}13.6 \\
(2.7)\end{array}$ & $\begin{array}{l}15.4 \\
(3.6)\end{array}$ & $\begin{array}{l}14.2 \\
(4.39)\end{array}$ & $\begin{array}{l}15.6 \\
(3.2)\end{array}$ & $\begin{array}{l}15.4 \\
(3.5)\end{array}$ & $\begin{array}{c}1.5 \\
(0.8)\end{array}$ \\
\hline 14 & $\begin{array}{c}20.8 \\
(5.5)\end{array}$ & $\begin{array}{l}18.4 \\
(4.3)\end{array}$ & $\begin{array}{l}15.4 \\
(3.1)\end{array}$ & $\begin{array}{l}17.4 \\
(3.9)\end{array}$ & $\begin{array}{l}16.4 \\
(5.29)\end{array}$ & $\begin{array}{l}17.4 \\
(3.8)\end{array}$ & $\begin{array}{l}17.6 \\
(4.32)\end{array}$ & $\begin{array}{l}1.8 \\
(0.90)\end{array}$ \\
\hline 28 & $\begin{array}{l}20.8 \\
(5.72)\end{array}$ & $\begin{array}{l}23.8 \\
(5.50)\end{array}$ & $\begin{array}{l}18.8 \\
(4.50)\end{array}$ & $\begin{array}{l}19.8 \\
(5.0)\end{array}$ & $\begin{array}{l}18.8 \\
(5.95)\end{array}$ & $\begin{array}{l}23.8 \\
(5.2)\end{array}$ & $\begin{array}{l}20.9 \\
(5.3)\end{array}$ & $\begin{array}{c}2.3 \\
(0.5)\end{array}$ \\
\hline 56 & $\begin{array}{c}29.8 \\
\text { (10.92) }\end{array}$ & $\begin{array}{l}22.8 \\
(7.00)\end{array}$ & $\begin{array}{l}19.8 \\
(6.00)\end{array}$ & $\begin{array}{l}22.8 \\
(6.0)\end{array}$ & $\begin{array}{l}20.8 \\
(6.84)\end{array}$ & $\begin{array}{l}20.8 \\
(6.6)\end{array}$ & $\begin{array}{l}22.8 \\
(7.29)\end{array}$ & $\begin{array}{c}3.6 \\
(1.8)\end{array}$ \\
\hline 91. & $\begin{array}{l}32.8 \\
(7.5)\end{array}$ & $\begin{array}{c}34.8 \\
(6.7)\end{array}$ & $\begin{array}{l}21.8 \\
(7.5)\end{array}$ & $\begin{array}{l}28.8 \\
(7.0)\end{array}$ & $\begin{array}{c}22.8 \\
(7.3)\end{array}$ & $\begin{array}{l}21.8 \\
(7.0)\end{array}$ & $\begin{array}{l}27.1 \\
(7.2)\end{array}$ & $\begin{array}{l}5.8 \\
(0.3)\end{array}$ \\
\hline 182 & $\begin{array}{l}27.3 \\
(6.22)\end{array}$ & $\begin{array}{l}26.8 \\
(5.92)\end{array}$ & $\begin{array}{l}22.8 \\
(5.42)\end{array}$ & $\begin{array}{l}24.8 \\
(6.12)\end{array}$ & $\begin{array}{l}30.8 \\
(6.89)\end{array}$ & $\begin{array}{l}25.8 \\
(6.62)\end{array}$ & $\begin{array}{l}26.4 \\
(6.2)\end{array}$ & $\begin{array}{c}2.7 \\
(0.5)\end{array}$ \\
\hline 273 & $\begin{array}{l}23.0 \\
(4.8)\end{array}$ & $\begin{array}{l}27.0 \\
(5.5)\end{array}$ & $\begin{array}{l}21.0 \\
(5.2)\end{array}$ & $\begin{array}{l}24.0 \\
(5.3)\end{array}$ & $\begin{array}{c}26.0 \\
(8.0)\end{array}$ & $\begin{array}{c}24.0 \\
(6.2)\end{array}$ & $\begin{array}{c}24.2 \\
(5.8)\end{array}$ & $\begin{array}{c}2.1 \\
(1.2)\end{array}$ \\
\hline 364 & $\begin{array}{c}50.8^{*} \\
(34.9)^{*}\end{array}$ & $\begin{array}{c}24.35 \\
(9.20)\end{array}$ & $\begin{array}{c}21.35 \\
(7.05)\end{array}$ & $\begin{array}{c}21.35 \\
(7.70)\end{array}$ & $\begin{array}{c}23.35 \\
(8.10)\end{array}$ & $\begin{array}{c}22.35 \\
(12.40)\end{array}$ & $\begin{array}{c}22.5 \\
(8.9)\end{array}$ & $\begin{array}{c}1.2 \\
(1.9)\end{array}$ \\
\hline
\end{tabular}

Another test performed on the same composition, but with an $S A / V=350 \mathrm{~m}^{-1}$, was performed for 182 days. Given that $S A / N * t$ was found to be a valid scaling parameter for this glass (Figure 8), the lack of accelerated corrosion in the latter test may confirm the spurious nature of the single test showing evidence of an acceleration in corrosion. 


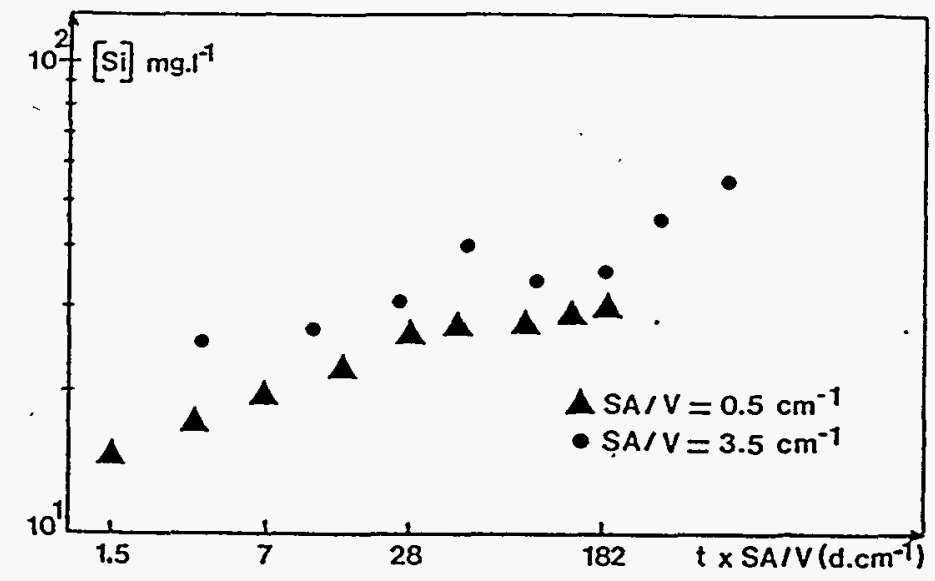

Figure 8. Corrosion behavior of R7T7 glass (reproduced from Fillet et al., 1986)

Caurel et al. (1990) performed hydrothermal tests on the R7T7 glass. Polished glass samples were leached at 150 and $250^{\circ} \mathrm{C}$ in double distilled or Volvic (granitic groundwater) water for periods up to one year. Saturated vapor pressure conditions were maintained in autoclaves.

At both temperatures, the silicon, boron, and sodium release rates decreased after one day from initial release values (as estimated separately from Soxhlet experiments), reaching quasi-steady state conditions between seven and 14 days (earlier at the higher temperature). After 30 or 21 days, respectively, both the 250 and $150^{\circ} \mathrm{C}$ tests showed an increase in dissolution rate. This increase was not satisfactorily explained in the $150^{\circ} \mathrm{C}$ case, as the alteration products were not deemed rich enough in silica to induce the increase; it was necessary to assume the dominance of polymeric silica species to explain the observations. The increase at $250^{\circ} \mathrm{C}$ was explained by the observation of glass cracking, which increased the reactive surface. In both cases, the accelerated rate had dissipated by about 200-250 days.

Vernaz et al. (1990) tested R7T7 glass at four SA/V ratios: $400 \mathrm{~m}^{-1}$ ("comb-shaped"specimens), 2000,8000 , and $20000 \mathrm{~m}^{-1}$ (powdered glass). A possible drawback of the test protocol was that different grain sizes were used to achieve the various SA/V of the powdered glass tests. No dissolution of the particles was reported, however, even though the tests were conducted up to one year. Unlike some of the other studies summarized in this report, Vernaz et al. observed a corrosion acceleration for the two lowest SA/V ratios, but not for the higher SAN ratios. It is possible that total dissolution was responsible for the apparent cessation of corrosion in the $S A / V=20000 \mathrm{~m}^{-1}$ test, as the boron concentration reached $350 \mathrm{ppm}$ and remained constant after about 100 days. The test at $\mathrm{SA} / \mathrm{V}=8000 \mathrm{~m}^{-1}$ showed a slowing of the initial rate, then a continuous increase in leachate concentrations over the test duration. The accelerated corrosion for the two lowest SA/V ratios are shown in Figure 9. Note that the results for $S A / V=400 \mathrm{~m}^{-1}$ should be roughly comparable to those of Fillet et al. (1986) for $S A / V=350 \mathrm{~m}^{-1}$; the latter did not report an acceleration of corrosion rate for this $\mathrm{SA} / \mathrm{N}$, however. 


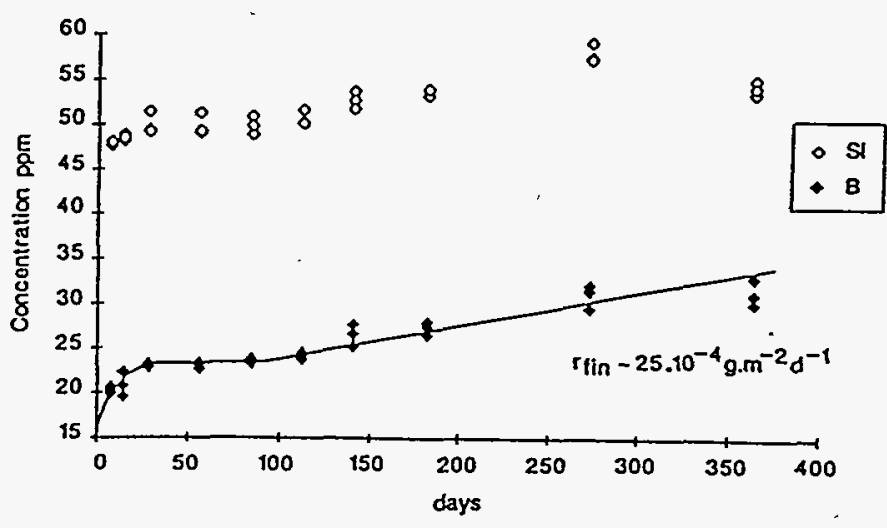

Figure 1: Silicon and Boron Concentrations versus Time for SA/V $-400 m^{-1}$

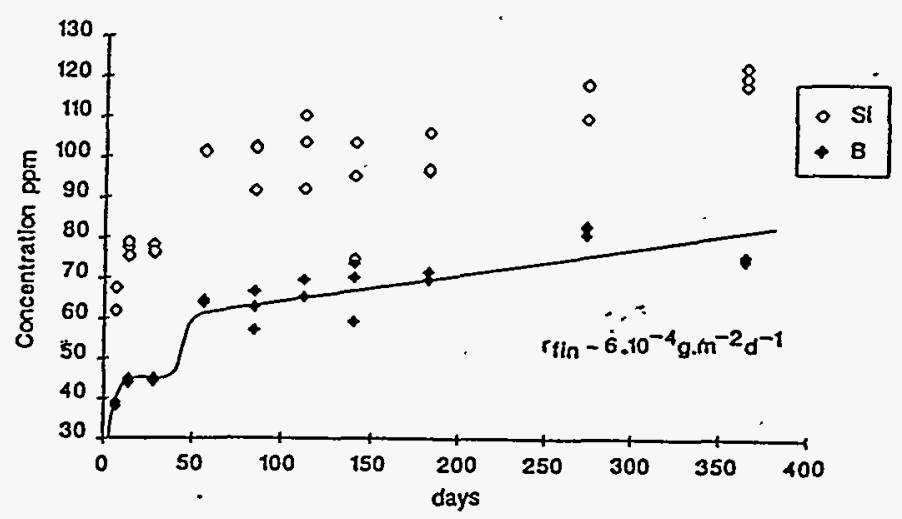

Figure 2 : Silicon and Boron Concentrations versus Time for $S A / V=2000 m^{-1}$

Figure 9. Corrosion behavior of R7T7 glass at $\mathrm{SA} / \mathrm{V}=400 \mathrm{~m}^{-1}$ and $2000 \mathrm{~m}^{-1}$ (reproduced from Vernaz et al., 1990)

\section{Multicomponent Borosilicate Glasses (Barkatt et al., 1991)}

Four multicomponent borosilicate glasses, chosen to be similar to West Valley waste glass compositions, were tested by Barkatt et al. (1991). The sodium oxide content of these glasses is somewhat lower than is of direct interest for Hanford LLW glass. A periodic * replenishment test procedure was used, in which one-fourth the leachate volume was periodically withdrawn and replaced with fresh water. The periodic replenishment technique makes the results somewhat difficult to relate to those of other static leaching tests. The dependence of corrosion mechanisms on solution saturation and precipitate formation implies that the periodic replenishment will cause a cycling of solution chemistry. This would disrupt the saturated conditions, assuming they have time to form between replenishments.

Of interest in these tests is the observation of reproducible, excursive leaching behavior (Figure 10). All major soluble components evidenced the excursive behavior when it occurred. Despite the reproducibility of the excursions, they were attributed to cracking of the glass surface. The accelerated leach rates did not persist in these experiments. They did not recur more than once in a given test, i.e., they were not associated with a specific point in the replenishment cycle, hence with a specific point in the approach to silica saturation. 
Boron Leach Rates of Various Glasses

DIW, $90 \mathrm{C}, \mathrm{S} / \mathrm{V}=970 / \mathrm{m}, \mathrm{Tr}=112 \mathrm{~d}$

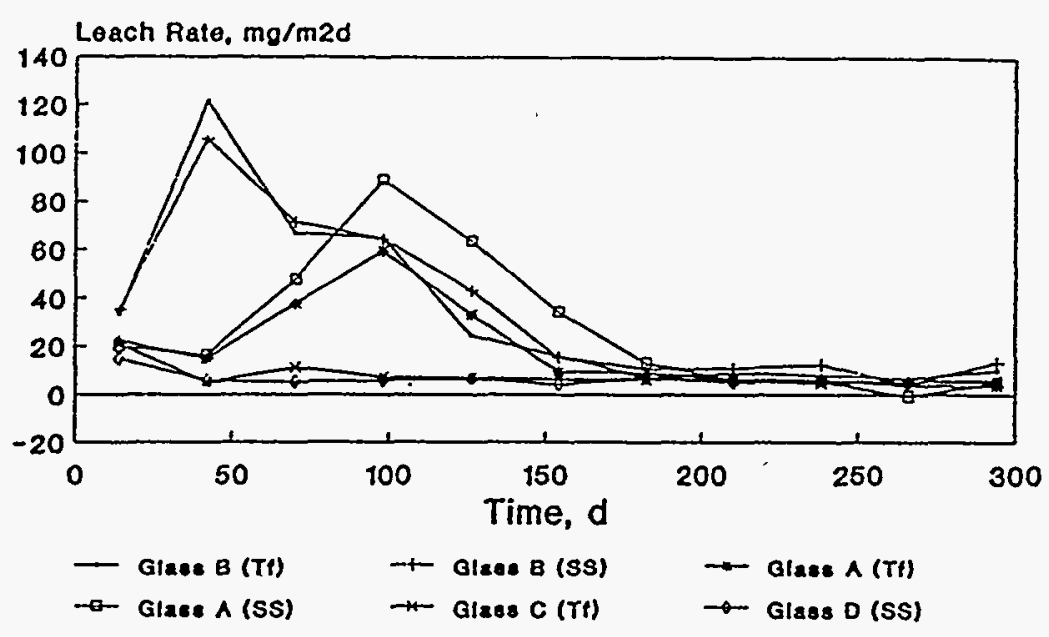

Figure 10. Leach rate excursions observed by Barkatt et al. (1991).

\section{CONCLUSIONS}

Accelerated corrosion rates have been observed under various test protocols and for various compositions relevant to the processing of high-level waste glass. Waste glass compositions in which accelerated corrosion has been observed include SRL 131, SRL 202, SAN60, SM58, and R7T7. Although most of these compositions are somewhat lower in sodium than those of interest for Hanford LLW glass formulations, the underlying mechanismis for accelerated corrosion are probably similar; the phenomenon is thus relevant to high-sodium glasses as well.

Ebert et al. (1993) observed accelerated corrosion in SRL 202-type glass (both radioactive and simulated), at high SA/V and high SA/V*t in PCT-type tests. Feng et al. (1993) tested glasses of similar composition; they reported corrosion acceleration for the simulated waste glass composition only. The acceleration behavior occurred at the same $\mathrm{SA} / \mathrm{V}$ and $\mathrm{SA} / \mathrm{V} *_{\mathrm{t}}$ as that reported by Ebert et al. (1993). The behavior was qualitatively different from that observed by Ebert et al. (1993), however, being more excursive in nature and appearing to return to a lower release rate fairly rapidly.

Accelerated corrosion data observed in SRL 131 glass by Ebert et al. (1993) can be compared to data on SRL 131 glass by Feng et al. (1993) and by Feng et al. (1990). Comparison of data from different tests sometimes requires the use of assumptions, such as the validity of $\mathrm{SA} / \mathrm{V}^{*} \mathrm{t}$ scaling. In the former case, no scaling assumption is necessary, as the same SA/V was used in both tests. The Feng et al. (1993) data did not show evidence of accelerated corrosion, however. Feng et al. (1990) showed that, while $S A / V * t$ scaling was composition-dependent, it was valid for SRL 131. At the $S A / V * t$ 
Accelerated corrosion data observed in SRL 131 glass by Ebert et al. (1993) can be compared to data on SRL 131 glass by Feng et al. (1993) and by Feng et al. (1990). Comparison of data from different tests sometimes requires the use of assumptions, such as the validity of SA/V*t scaling. In the former case, no scaling assumption is necessary, as the same SA/V was used in both tests. The Feng et al. (1993) data did not show evidence of accelerated corrosion, however. Feng et al. (1990) showed that, while $S A / V * t$ scaling' was composition-dependent, it was valid for SRL 131. At the SA/V*t associated with corrosion acceleration in the Ebert et al. (1993) tests, no accelerated corrosion was observed, however.

Acceleration was also observed in SRL 202 glass by Ebert and Bates (1990) under a quite different test protocol, that of vapor hydration testing. Comparison of the results from vapor hydration tests with PCT/MCC-1 results is somewhat problematical, in that the secondary phase morphology is not always identical. The measure of corrosion discussed by Ebert and Bates (1990) is the growth of alteration layer depth, rather than the leachate analyses used in static tests such as the PCT. Acceleration was also observed for WVCM40 and WVCM50 glasses under vapor hydration testing, whereas SRL 165 appeared to have a steady, non-negligible corrosion rate without the plateau phase of Figure 1. Accelerated leaching was not observed in SRL 165 glass by Feng et al. (1993).

Tests of R7T7 glass also showed apparent contradictions. The tests of Fillet et al. (1986) at $S A / V=350 \mathrm{~m}^{-1}$ should be roughly comparable to those of Vernaz et al. at $400 \mathrm{~m}^{-1}$. Accelerated corrosion was not observed in the former, but was observed in the latter. Fillet et al. did observe an acceleration in the corrosion rate for one test out of a total of eight replicates at $\mathrm{SA} / \mathrm{V}=50 \mathrm{~m}^{-1}$, but considered this single result to be spurious.

Accelerated leaching was observed in the SAN60 and SM58 glasses. Attempts to model these data by Van Iseghem and Grambow (1988) and by Patyn et al. (1990) in terms of stability fields and precipitation of secondary phases were only partially successful.

Given a range of $S A / N *$ t over which acceleration has been observed, tests which do not show an acceleration within this range also yield important data. Such tests were performed by Ramsey (1995), i.e., 30 glasses subjected to PCT-type testing of up to 26 weeks' duration. These glasses are particularly relevant to Hanford LLW glass compositions, as most of them have significant sodium oxide content. None of these glasses showed an acceleration in corrosion, although the lack of data between four and 26 weeks renders the assessment somewhat indefinite in some cases. The tests spanned-the SA/V*t at which acceleration was observed by Ebert et al. (1993) in SRL 131 glass, and included glasses fairly close in composition to SRL 131.

An explanation for the occurrance of accelerated corrosion, after a quasi-steady state rate which is often (though not always) quite small, lies in the precipitation of secondary phases. The precipitation of certain phases (analcime and clinoptilolite have been observed for waste glasses SAN60 and SRL 202) may induce breakdown of the silicate glass matrix. Whether this occurs is highly dependent on the solution chemistry, which in turn depends on the original glass composition, the $\mathrm{SA} / \mathrm{V}$, and any replenishment schedule for the leaching solution.

Despite the somewhat contradictory results of Van Iseghem and Grambow (1988) and Patyn et al. (1990), wherein the stability of SM58 was predicted, but accelerated corrosion was observed in a subsequent test, reaction path modeling seems the most rational way to predict whether corrosion acceleration will occur. As in the contrasting examples of SAN60 and SM58, if the original glass composition has adequate silica content for the 
incipient secondary phase, then sufficient silica will be in solution and precipitation does not lead to corrosion acceleration.

Given a dependence of the acceleration phenomenon on solution chemistry and paragenetic sequence, the glass composition alone is not expected to determine whether corrosion acceleration will occur. The total environment must be considered, including groundwater chemistry and flow behavior, and the chemistry of the surrounding materials. Most tests have not addressed these issues directly; those which attempt to do so (such as the vapor hydration test as a simulation of burial in unsaturated conditions) are of necessity tied to particular types of disposal scenarios. Although some tests have been performed with equilibrated groundwaters, little work has been done to include the effect of the surrounding material. Godon and Vernaz (1990) reported tests of R7T7 glass corrosion in the presence of various moist clays. As with precipitation of secondary phases from the leaching solution, clay phases can consume silicon, thus keeping corrosion rates elevated. The duration of the acceleration was related to the ratio between clay mass and glass surface area. To predict whether a glass will be susceptible to accelerated corrosion would thus appear to require consideration of the entire near-field disposal environment.

In summary, the phenomenon of an increase in corrosion rate, following a period characterized by a low (sometimes negligible) corrosion rate, has been observed by a number of researchers on a number of waste glass compositions. Despite inherent ambiguities arising from $\mathrm{SA} / \mathrm{V}$ and other effects, valid comparisons can be made in which accelerated corrosion was observed in one test (for a given glass composition ), but not in another. Some glass compositions do not appear to attain a plateau region (cf. Figure 1); it may be that the observation of continued, non-negligible corrosion in these glasses represents a passage from the initial rate ("Phase 1") to the "accelerated" rate ("Phase 3"). The long-term corrosion is a function of the interaction between the glass and its environment, including the leaching solution (its chemistry, volume, and flow) and the surrounding materials. Reaction path modeling and stability field considerations have been used with some success to predict the changes in corrosion rate over time, due to these interactions. The accelerated corrosion phenomenon highlights the need for such integrated corrosion modeling and the scenario-specific nature of a particular glass composition's durability.

\section{REFERENCES}

Barkatt, Aa., Olszowka, S. A., Sousanpour, W., Adel-Hadadi, M. A., Adiga, R.; Barkatt, Al., Marbury, G. S., and Li, S., 1991, "Leach Rate Excursions in Borosilicate Glasses: Effects of Glass and Leachant Composition," Mat. Res. Soc. Symp. Proc., Vol. 212 , pp. 65-76.

Bourcier, W. L., 1995, personal communication.

Bourcier, W. L., Ebert, W. L., and Feng, X., 1993, "Modeling Surface Area to Volume Effects on Borosilicate Glass Dissolution," Mat. Res. Soc. Symp. Proc., Vol. 294, pp. $577-582$.

Caurel, J., Vernaz, E., and Beaufort, D., 1990, "Hydrothermal Leaching of R7-T7 Borosilicate Glass," Mat. Res. Soc. Symp. Proc., Vol. 176, pp. 309-317.

Cunnane, J. C., ed., 1994, "High-Level Waste Borosilicate Glass: A compendium of Corrosion Characteristics," Vol. II, pp. 77-87. 
Ebert, W. L., and Bates, J. K., 1990, "The Reaction of Synthetic Nuclear Waste Glass in Steam and Hydrothermal Solution," Mat. Res. Soc. Symp. Proc., Vol. 176, pp. 339-346.

Ebert, W. L., and Bates, J. K., 1993, "A Comparison of Glass Reaction at High and Low Glass Surface/Solution Volume," Nuclear Tech., Vol. 104, pp-372-384.

Ebert, W. L., Bates, J. K., Buck, E. C., and Bradley, C. R., 1993, "Accelerated Glass Reaction Under PCT Conditions," Mat. Res. Soc. Symp. Proc., Vol. 294, pp. 5.69-576.

Feng, X., and Pegg, I., 1994, "A Glass Dissolution Model for the Effects of S/V on Leachate pH," J. Non-Cryst. Sol., Vol. 175, pp. 281-293.

Feng, X., Pegg, I. L., Guo, Y., Aa. Barkatt, and Macedo, P. B., 1990, "Effects of Surface Area-to-Solution Volume Ratio on Chemical Durability of Nuclear Waste Glasses," Mat. Res. Soc. Symp. Proc., Vol. 176, pp. 383-392.

Feng, X., Bates, J. K., Buck, E. C., Bradley, C. R., and Gong, M., 1993, "Long-Term Comparison of Dissolution Behavior Between Fully Radioactive and Simulated Nuclear Waste Glasses," Nucl. Tech., Vol. 104, pp. 193-206.

Fillet, S., Vernaz, E., Nogues, J. L., and Jacquet-Francillon, N., 1986, "Corrosion Rate of Nuclear Glass in Saturated Media," Adv. Cer. Vol. 20: Nucl. Waste Mgmt. II, pp. 443453.

Godon, N., and Vernaz, E., 1990, "R7T7 Nuclear Waste Glass Behavior in Moist Clay: Role of the Clay Mass/Glass Surface Area Ratio," Mat. Res. Soc. Symp. Proc., Vol. 176, pp. 319-326.

Patyn, J., Van Iseghem, P., and Timmermans, W., 1990, "The Long-Term Corrosion and Modelling of Two Simulated Belgian Reference High-Level Waste Glasses-Part II," Mat. Res. Soc. Symp. Proc., Vol. 176, pp. 299-307.

Ramsey, W. G., 1995, "Glass Dissolution Chemistry of the System Na2O-B2O3-SiO2$\mathrm{Al}_{2} \mathrm{O}_{3}-\mathrm{Fe}_{2} \mathrm{O}_{3}-\mathrm{CaO}$," Clemson University Ph.D. Dissertation.

Shade, J. W., and Strachan, D. M., 1986, "Effect of High Surface Area to Solution Volume Ratios on Waste Glass Leaching," Cer. Bull., Vol. 76, No. 12, pp. 1568-1573.

Van Iseghem, P., and Grambow, B., 1988, "The Long-Term Corrosion and Modelling of Two Simulated Belgian Reference High-Level Waste Glasses," Mat. Res. Soc. Symp.

Proc., Vol. 112, pp. 631-639.

Vernaz, E., Advocat, T., and Dussossoy, J. L., "Effects of the SA/V Ratio on the LongTerm Corrosion Kinetics of R7-T7 Glass," Nuclear Waste Mgmt. III, G. B. Mellinger, ed., Cer. Trans., Vol 9, pp. 175-185. 


\section{APPENDIX 1 \\ GLASS COMPOSITIONS}

All compositions in weight percent

\begin{tabular}{|c|c|c|c|c|}
\hline & $\begin{array}{l}\text { SRL 131A } \\
\text { (Ebert et al., } \\
\text { 1993) }\end{array}$ & $\begin{array}{l}\text { SRL 202A } \\
\text { (Ebert et al., } \\
\text { 1993) }\end{array}$ & $\begin{array}{l}\text { SM58LW11 } \\
\text { (Van Iseghem } \\
\text { and } \\
\text { Grambow, } \\
\text { 1988) }\end{array}$ & $\begin{array}{l}\text { SAN602519- } \\
\text { L }_{3} \mathrm{C}_{2} \\
\text { (Van Iseghem } \\
\text { and } \\
\text { Grambow, } \\
\text { 1988) } \\
\end{array}$ \\
\hline $\mathrm{Am}_{2} \mathrm{O}_{3}$ & .0004 & .0004 & & \\
\hline $\mathrm{Al}_{2} \mathrm{O}_{3}$ & 3.27 & 3.84 & 1.2 & 18.1 \\
\hline $\mathrm{B}_{2} \mathrm{O}_{3}$ & 9.65 & 7.97 & 12.3 & 17.0 \\
\hline $\mathrm{BaO}$ & 0.16 & 0.22 & & \\
\hline $\mathrm{CaO}$ & 0.93 & 1.2 & 3.8 & 3.5 \\
\hline $\mathrm{CuO}$ & 0.02 & 0.4 & & \\
\hline $\mathrm{Cr}_{2} \mathrm{O}_{3}$ & 0.13 & 0.08 & & \\
\hline $\mathrm{Fe}_{2} \mathrm{O}_{3}$ & 12.7 & 11.4 & 1.2 & 0.3 \\
\hline $\mathrm{K}_{2} \mathrm{O}$ & 3.86 & 3.71 & & \\
\hline \multicolumn{5}{|l|}{$\mathrm{La}_{2} \mathrm{O}_{3}$} \\
\hline $\mathrm{Li}_{2} \mathrm{O}$ & 3.0 & 4.23 & 3.7 & 5.0 \\
\hline $\mathrm{MgO}$ & 1.31 & 1.32 & 2.0 & \\
\hline $\mathrm{MnO}_{2}$ & 2.43 & 2.21 & & \\
\hline $\mathrm{MoO}_{3}$ & & 0.05 & & \\
\hline $\mathrm{Na}_{2} \mathrm{O}$ & 12.1 & 8.92 & 8.3 & 10.7 \\
\hline $\mathrm{NpO}_{2}$ & 0.009 & 0.01 & & \\
\hline $\mathrm{NiO}$ & 1.24 & 0.82 & & \\
\hline $\mathrm{PbO}$ & & 0.1 & & \\
\hline $\mathrm{PuO}_{2}$ & 0.009 & 0.01 & & \\
\hline $\mathrm{SiO}_{2}$ & 43.8 & 48.9 & 56.9 & 43.4 \\
\hline $\mathrm{SrO}$ & 0.01 & 0.03 & & \\
\hline $\mathrm{ThO}_{2}$ & & 0.26 & & \\
\hline $\mathrm{TiO}_{2}$ & 0.65 & 0.91 & 4.4 & \\
\hline $\mathrm{U}_{3} \mathrm{O}_{8}$ & 2.73 & 1.93 & & \\
\hline $\mathrm{ZnO}$ & 0.02 & 0.02 & 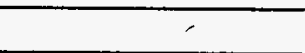 & \\
\hline $\mathrm{ZrO}_{2}$ & 0.22 & 0.10 & & \\
\hline $\begin{array}{l}\text { Fission } \\
\text { products }+ \\
\text { actinides + } \\
\text { nonmajor } \\
\text { oxides }\end{array}$ & & & 6.2 & 2.0 \\
\hline
\end{tabular}




\begin{tabular}{|c|c|c|c|c|c|c|}
\hline & $\begin{array}{l}\text { SRL } \\
131 / 11 R \\
\text { (Feng et } \\
\text { al., } \\
1993 \text { ) } \\
\end{array}$ & $\begin{array}{l}\text { SRL } \\
\text { 131/11S } \\
\text { (Feng et } \\
\text { al.,b } \\
\text { 1993) }\end{array}$ & $\begin{array}{l}\text { SRL } \\
200 R \\
\text { (Feng et } \\
\text { al., } \\
1993 \text { ) } \\
\end{array}$ & \begin{tabular}{|l} 
SRL \\
$200 S$ \\
(Feng et \\
al., \\
1993 ) \\
\end{tabular} & \begin{tabular}{|l|} 
SRL \\
165/42R \\
(Feng et \\
al., \\
1993) \\
\end{tabular} & \begin{tabular}{|l|} 
SRL \\
165/42S \\
(Feng et \\
al., \\
1993) \\
\end{tabular} \\
\hline $\mathrm{Am}_{2} \mathrm{O}_{3}$ & $9.05 \mathrm{E}-5$ & & & & $9.5 \mathrm{E}-5$ & \\
\hline $\mathrm{Al}_{2} \mathrm{O}_{3}$ & 9.7 & 9.2 & 5.9 & 5.5 & 10.36 & 8.7 \\
\hline $\mathrm{B}_{2} \mathrm{O}_{3}$ & 9.4 & 9.3 & 9.7 & 9.6 & 8.02 & 8.4 \\
\hline $\mathrm{BaO}$ & 0.02 & 0.05 & 0.02 & 0.03 & & 0.4 \\
\hline $\mathrm{CaO}$ & 3.9 & 2.9 & 0.9 & 0.9 & 0.33 & 0.3 \\
\hline $\mathrm{CuO}$ & 0.02 & 0.04 & $0: 1$ & 0.1 & 0.03 & 0.06 \\
\hline $\mathrm{Cr}_{2} \mathrm{O}_{3}$ & 0.9 & 0.7 & 0.3 & 0.2 & 0.33 & 0.8 \\
\hline $\mathrm{Cs}_{2} \mathrm{O}$ & $1.7 \mathrm{E}-8$ & & & & $1.1 \mathrm{E}-4$ & \\
\hline $\mathrm{Fe}_{2} \mathrm{O}_{3}$ & 4.8 & 5.1 & 9.0 & 8.8 & 5.89 & 6.1 \\
\hline $\mathrm{K}_{2} \mathrm{O}$ & 0.06 & 0.1 & 3.5 & 3.3 & 0.05 & 0.08 \\
\hline $\mathrm{La}_{2} \mathrm{O}_{3}$ & & & 0.06 & 0.01 & & \\
\hline $\mathrm{Li}_{2} \mathrm{O}$ & 3.3 & 3.2 & 3.4 & 3.3 & 4.72 & 4.7 \\
\hline $\mathrm{MgO}$ & 1.4 & 1.6 & 1.6 & 1.7 & 1.02 & 1.0 \\
\hline $\mathrm{MnO}_{2}$ & 1.7 & 1.7 & 1.6 & 1.5 & 1.94 & 1.8 \\
\hline $\mathrm{MoO}_{3}$ & & & 0.01 & 0.02 & & \\
\hline $\mathrm{Na}_{2} \mathrm{O}$ & 16.6 & 17.5 & 15.0 & 16.0 & .11 .12 & 10.8 \\
\hline $\mathrm{Nd}_{2} \mathrm{O}_{3}$ & & & 0.1 & & & \\
\hline $\mathrm{NiO}$ & 0.5 & 0.6 & 0.9 & 0.9 & 0.61 & 0.8 \\
\hline $\mathrm{PbO}$ & 0.02 & 0.1 & 0.03 & 0.05 & 0.05 & 0.01 \\
\hline $\mathrm{PuO}_{2}$ & $2.7 \mathrm{E}-4$ & & & & $1.7 \mathrm{E}-4$ & \\
\hline $\mathrm{SiO}_{2}$ & 45.5 & 45.8 & 45.5 & 45.4 & TBA & 52.4 \\
\hline $\mathrm{SrO}$ & 0.02 & 0.02 & 0.01 & 0.02 & 0.04 & 0.01 \\
\hline $\mathrm{ThO}_{2}$ & & & & & & 0.01 \\
\hline $\mathrm{TiO}_{2}$ & 1.5 & 1.7 & 0.08 & 0.1 & & 0.08 \\
\hline $\mathrm{U}_{3} \mathrm{O}_{8}$ & 0.25 & 0.26 & 1.8 & 1.9 & TBA & 0.1 \\
\hline $\mathrm{ZnO}$ & 0.02 & 0.05 & 0.02 & 0.04 & 0.03 & 0.1 \\
\hline $\mathrm{ZrO}_{2}$ & 0.08 & 0.1 & 0.06 & 0.09 & 0.83 & 1.4 \\
\hline
\end{tabular}




\begin{tabular}{|c|c|c|c|c|}
\hline & $\begin{array}{l}\text { WVCM44 } \\
\text { (Ebert and } \\
\text { Bates, } \\
\text { 1990) }\end{array}$ & $\begin{array}{l}\text { WVCM50 } \\
\text { (Ebert and } \\
\text { Bates, } \\
\text { 1990) }\end{array}$ & $\begin{array}{l}\text { SRL165U } \\
\text { (Ebert and } \\
\text { Bates, } \\
\text { 1990) }\end{array}$ & $\begin{array}{l}\text { SRL 202U } \\
\text { (Ebert and } \\
\text { Bates, } \\
\text { 1990) }\end{array}$ \\
\hline $\mathrm{Al}_{2} \mathrm{O}_{3}$ & 6.14 & 9.86 & 4.08 & 4.76 \\
\hline $\mathrm{B}_{2} \mathrm{O}_{3}$ & 8.42 & 12.27 & 6.76 & 8.06 \\
\hline $\mathrm{BaO}$ & 0.05 & 0.19 & 0.06 & \\
\hline $\mathrm{CaO}$ & 0.99 & 0.82 & 1.62 & 0.79 \\
\hline \multicolumn{5}{|l|}{$\mathrm{CuO}$} \\
\hline $\mathrm{CeO}$ & 0.06 & 0.07 & $<0.05$ & \\
\hline $\mathrm{Cr}_{2} \mathrm{O}_{3}$ & 0.03 & 0.14 & $<0.01$ & \\
\hline $\mathrm{Cs}_{2} \mathrm{O}$ & 0.07 & 0.07 & 0.07 & 0.07 \\
\hline $\mathrm{Fe}_{2} \mathrm{O}_{3}$ & 11.4 & 11.93 & 11.74 & 12.05 \\
\hline $\mathrm{K}_{2} \mathrm{O}$ & 3.63 & 1.60 & & 3.21 \\
\hline $\mathrm{Li}_{2} \mathrm{O}$ & 2.8 & 2.22 & 4.18 & 4.69 \\
\hline $\mathrm{MgO}$ & 1.38 & 0.79 & 0.70 & 1.47 \\
\hline $\mathrm{MnO}_{2}$ & 1.29 & 1.21 & 2.79 & 3.47 \\
\hline $\mathrm{Na}_{2} \mathrm{O}$ & 9.10 & 9.79 & 10.85 & 6.75 \\
\hline $\mathrm{NiO}$ & 0.42 & 0.30 & 0.85 & 1.03 \\
\hline $\mathrm{P}_{2} \mathrm{O}_{5}$ & 2.20 & 2.47 & 0.02 & \\
\hline $\mathrm{SiO}_{2}$ & 45.80 & 39.60 & 52.86 & 51.22 \\
\hline $\mathrm{SrO}$ & & 0.02 & 0.11 & 0.13 \\
\hline $\mathrm{ThO}_{2}$ & 3.30 & 3.52 & & \\
\hline $\mathrm{TiO}_{2}$ & 0.88 & 0.82 & 0.14 & 1.32 \\
\hline $\mathrm{UO}_{2}$ & 0.70 & 0.61 & 0.92 & 1.08 \\
\hline $\mathrm{ZrO}_{2}$ & 0.29 & 0.39 & 0.66 & \\
\hline
\end{tabular}


GLASSES FROM RAMSEY (1995) STUDY

\begin{tabular}{|l|l|l|l|l|l|l|l|}
\hline $\begin{array}{l}\text { GIass } \\
\text { ID }\end{array}$ & $\mathbf{A l}_{2} \mathbf{O}_{3}$ & $\mathbf{B}_{2} \mathbf{O}_{3}$ & $\mathbf{C a O}$ & $\mathbf{F e}_{2} \mathbf{O}_{3}$ & $\mathbf{F e O}$ & $\mathbf{N a}_{2} \mathbf{O}$ & $\mathbf{S i O}_{2}$ \\
\hline MG 1 & 16.136 & 14.820 & 0.000 & 0.000 & 0.000 & 14.056 & 54.988 \\
MG 2 & 16.338 & 5.320 & 8.960 & 0.000 & 0.000 & 14.629 & 54.753 \\
MG 4 & 17.207 & 4.564 & 0.000 & 0.000 & 0.000 & 23.187 & 55.042 \\
MG 5 & 5.672 & 15.148 & 8.590 & 0.000 & 0.000 & 14.207 & 56.383 \\
MG 6 & 4.203 & 12.719 & 0.000 & 19.369 & 2.561 & 12.143 & 49.005 \\
MG 7 & 1.016 & 16.182 & 0.000 & 0.000 & 0.000 & 25.454 & 57.348 \\
MG 8 & 3.666 & 4.699 & 7.474 & 18.867 & 2.973 & 12.594 & 49.727 \\
MG 9 & 0.202 & 5.633 & 9.259 & 0.000 & 0.000 & 25.970 & 58.937 \\
MG 10 & 2.407 & 4.073 & 0.000 & 18.138 & 3.021 & 22.706 & 49.654 \\
MG 11 & 16.755 & 16.285 & 8.841 & 0.000 & 0.000 & 14.244 & 43.875 \\
MG 13 & 18.263 & 14.469 & 0.000 & 0.000 & 0.000 & 22.351 & 44.917 \\
MG 15 & 17.510 & 4.832 & 8.419 & 0.000 & 0.000 & 22.883 & 46.356 \\
MG 16 & 14.844 & 4.114 & 0.000 & 18.746 & 2.171 & 19.404 & 40.721 \\
MG 17 & 11.443 & 12.964 & 6.962 & 15.820 & 3.384 & 11.541 & 37.886 \\
MG 18 & 0.941 & 16.108 & 9.316 & 0.000 & 0.000 & 25.850 & 47.785 \\
MG 19 & 3.677 & 12.738 & 0.000 & 19.959 & 1.455 & 23.471 & 38.699 \\
MG 20 & 0.965 & 4.879 & 7.860 & 21.999 & 1.350 & 21.551 & 41.395 \\
MG 21 & 11.250 & 8.807 & 3.164 & 8.775 & 0.844 & 16.983 & 50.177 \\
MG 22 & 18.431 & 9.465 & 4.164 & 10.900 & 1.665 & 16.005 & 39.369 \\
MG 23 & 22.607 & 7.620 & 2.791 & 6.662 & 1.646 & 15.793 & 42.881 \\
MG 24 & 7.415 & 10.491 & 4.568 & 12.241 & 1.735 & 17.210 & 46.339 \\
MG 25 & 12.964 & 13.712 & 3.012 & 8.228 & 1.157 & 15.473 & 45.454 \\
MG 26 & 11.156 & 4.359 & 4.576 & 11.410 & 2.540 & 17.605 & 48.354 \\
MG 27 & 14.503 & 8.100 & 7.682 & 7.782 & 1.283 & 15.701 & 44.950 \\
MG 28 & 14.634 & 9.225 & 0.000 & 11.189 & 2.151 & 16.863 & 45.937 \\
MG 29 & 11.479 & 7.339 & 2.666 & 17.252 & 2.980 & 14.006 & 44.279 \\
MG 30 & 10.702 & 12.270 & 5.519 & 0.000 & 0.000 & 19.575 & 51.934 \\
MG 31 & 14.831 & 7.843 & 2.996 & 8.021 & 1.137 & 20.695 & 44.477 \\
MG 32 & 16.340 & 9.311 & 4.303 & 10.010 & 2.873 & 12.306 & 44.857 \\
MG 33 & 17.930 & 8.701 & 3.436 & 8.466 & 1.853 & 15.810 & 43.805 \\
& & & & &. & & \\
\hline
\end{tabular}




\begin{tabular}{|c|c|c|c|}
\hline & $\begin{array}{l}\text { HW-39 } \\
\text { (Feng et al., } \\
\text { 1990)* }\end{array}$ & $\begin{array}{l}\text { SF6/WV205 } \\
\text { (Feng et al., } \\
\text { 1990)*\# }\end{array}$ & $\begin{array}{l}\text { PNL 76-68 } \\
\text { (Shade and } \\
\text { Strachan, } \\
1986)^{*}\end{array}$ \\
\hline $\mathrm{Al}_{2} \mathrm{O}_{3}$ & 4.3 & 3.31 & 0.6 \\
\hline $\mathrm{B}_{2} \mathrm{O}_{3}$ & 9.6 & 9.97 & 8.81 \\
\hline $\mathrm{BaO}$ & 0.2 & 0.06 & 0.53 \\
\hline $\mathrm{CaO}$ & 2.9 & 0.61 & 2.36 \\
\hline $\mathrm{CuO}$ & 0.1 & & \\
\hline $\mathrm{CeO}_{2}$ & & 0.18 & 0.09 \\
\hline $\mathrm{Cr}_{2} \mathrm{O}_{3}$ & 1.3 & 0.22 & \\
\hline $\mathrm{Cs}_{2} \mathrm{O}$ & 0.2 & 0.11 & 1.02 \\
\hline $\mathrm{Fe}_{2} \mathrm{O}_{3}$ & 11.1 & 11.83 & 9.4 \\
\hline $\mathrm{K}_{2} \mathrm{O}$ & & 3.62 & \\
\hline $\mathrm{La}_{2} \mathrm{O}_{3}$ & 0.5 & 0.12 & 4.06 \\
\hline $\mathrm{Li}_{2} \mathrm{O}$ & 3.8 & 3.0 & 0.0 \\
\hline $\mathrm{MgO}$ & 0.8 & 1.24 & 0.15 \\
\hline $\mathrm{MnO}_{2}$ & & 1.73 & \\
\hline $\mathrm{MoO}_{3}$ & 0.3 & & 1.93 \\
\hline $\mathrm{Na}_{2} \mathrm{O}$ & 10.4 & 11.05 & 11.53 \\
\hline $\mathrm{Nd}_{2} \mathrm{O}_{3}$ & 0.5 & & 1.38 \\
\hline $\mathrm{NiO}$ & 0.6 & 0.7 & \\
\hline $\mathrm{P}_{2} \mathrm{O}_{5}$ & & 2.52 & 0.7 \\
\hline $\mathrm{SO}_{3}$ & 0.04 & 0.14 & \\
\hline $\mathrm{SiO}_{2}$ & 51.3 & 45.25 & 40.84 \\
\hline $\mathrm{SrO}$ & & 0.13 & 0.42 \\
\hline $\mathrm{SnO}_{2}$ & & 0.13 & \\
\hline $\mathrm{TiO}_{2}$ & & .99 & 3.13 \\
\hline \multicolumn{4}{|l|}{$\mathrm{U}_{3} \mathrm{O}_{8}$} \\
\hline $\mathrm{ZnO}$ & & & 4.72 \\
\hline $\mathrm{ZrO}_{2}$ & 0.6 & 299 & 1.68 \\
\hline
\end{tabular}

* Compositions not given in original reference; reproduced here from Ebert (1994) -

\# SF6 glass of Feng et al. (1990) is same composition as WV205 (reproduced here from Ebert, 1994); SF10 = WV205+3.5 wt\% Al2O3; WVCM47 differs from WV205 in its $\mathrm{Al2O} / \mathrm{SiO} 2$ wt\% ratio of 8/42; WVCM50 differs from WV205 in its $\mathrm{Al} 2 \mathrm{O} 3 / \mathrm{SiO} 2 \mathrm{wt} \%$ ratio of 10/40; WVCM59 differs from WV205 in its Al2O3/SiO2 wt\% ratio of 6.5/41 per Feng et al. (1990) 


\begin{tabular}{|c|c|c|c|c|c|}
\hline & $\begin{array}{l}\text { Glass A } \\
\text { (Barkatt et } \\
\text { al., 1991) }\end{array}$ & $\begin{array}{l}\text { Glass B } \\
\text { (Barkatt et } \\
\text { al., 1991) }\end{array}$ & $\begin{array}{l}\text { Glass C } \\
\text { (Barkatt et } \\
\text { al., 1991) }\end{array}$ & $\begin{array}{l}\text { Glass D } \\
\text { (Barkatt et } \\
\text { al., 1991) }\end{array}$ & $\begin{array}{l}\text { R7T7 } \\
\text { (Caurel et } \\
\text { al., 1990) }\end{array}$ \\
\hline $\mathrm{Ag}_{2} \mathrm{O}$ & & & & & 0.03 \\
\hline $\mathrm{Al}_{2} \mathrm{O}_{3}$ & 4.27 & 2.89 & 9.86 & 6.45 & 4.91 \\
\hline $\mathrm{B}_{2} \mathrm{O}_{3}$ & 11.32 & 10.15 & 12.27 & 12.89 & 14.02 \\
\hline $\mathrm{BaO}$ & & & & & 0.60 \\
\hline $\mathrm{CaO}$ & 0.80 & 0.63 & 0.82 & 0.68 & 4.04 \\
\hline $\mathrm{CdO}$ & & & & & 0.03 \\
\hline $\mathrm{Ce}_{2} \mathrm{O}_{3}$ & & & & & 0.93 \\
\hline $\mathrm{CoO}$ & & & & & 0.12 \\
\hline $\mathrm{C}_{2} \mathrm{O}_{3}$ & & & & & 0.51 \\
\hline $\mathrm{Cs}_{2} \mathrm{O}$ & & & & & 1.42 \\
\hline $\mathrm{Fe}_{2} \mathrm{O}_{3}$ & 11.25 & 12.41 & 11.93 & 12.02 & 2.91 \\
\hline $\mathrm{K}_{2} \mathrm{O}$ & 3.03 & 3.65 & 1.60 & 3.18 & \\
\hline $\mathrm{La}_{2} \mathrm{O}_{3}$ & & & & & 0.90 \\
\hline $\mathrm{Li}_{2} \mathrm{O}$ & 3.05 & 3.09 & 2.22 & 2.71 & 1.98 \\
\hline $\mathrm{MgO}$ & 1.37 & 1.07 & 0.79 & 0.89 & \\
\hline $\mathrm{MnO}_{2}$ & 1.98 & 1.34 & 1.21 & 1.01 & $0.72 \mathrm{MnO}_{3}$ \\
\hline $\mathrm{MoO}_{3}$ & & & & & 1.70 \\
\hline $\mathrm{Na}_{2} \mathrm{O}$ & 10.23 & 11.15 & 9.79 & 9.82 & 9.86 \\
\hline $\mathrm{Nd}_{2} \mathrm{O}_{3}$ & & & & & 1.59 \\
\hline $\mathrm{NiO}$ & 0.60 & 0.90 & 0.30 & 0.25 & 0.74 \\
\hline $\mathrm{P}_{2} \mathrm{O}_{5}$ & 2.31 & 2.56 & 2.47 & 2.37 & 0.28 \\
\hline $\mathrm{Pr}_{2} \mathrm{O}_{3}$ & & & & & 0.44 \\
\hline $\mathrm{Sb}_{2} \mathrm{O}_{3}$ & & & & & 0.01 \\
\hline $\mathrm{SiO}_{2}$ & 44.88 & 45.74 & 39.60 & 41.16 & 45.48 \\
\hline $\mathrm{SnO}_{2}$ & & & & & 0.02 \\
\hline $\mathrm{SrO}$ & & & & & 0.33 \\
\hline $\mathrm{TeO}_{3}$ & & & & & 0.23 \\
\hline $\mathrm{ThO}_{2}$ & & & 3.52 & 3.56 & 0.33 \\
\hline $\mathrm{TiO}_{2}$ & 1.06 & 0.73 & 0.82 & 0.80 & \\
\hline $\mathrm{U}_{3} \mathrm{O}_{8}$ & & & 0.63 & 0.61 & $0.52 \mathrm{UO}_{2}$ \\
\hline $\mathrm{Y}_{2} \mathrm{O}_{3}$ & & & & & 0.20 \\
\hline $\mathrm{ZnO}$ & & & & & 2.50 \\
\hline$\overline{\mathrm{ZrO}_{2}}$ & 2.94 & 2.67 & 0.39 & 0.32 & 2.65 \\
\hline
\end{tabular}




\section{DISTRIBUTION}

L. M. Papouchado, 773-A

E. W. Holtzscheiter, 773-A

E. F. Duhn, 773-A

M. J. Plodinec, 773-A

C. T. Randall, 704-1T

L. Landon, 704-1T

D. A. Crowley, 704-1T

M. K. Andrews, 773-A

D. C. Beam, 773-A

N. E. Bibler, 773-A

D. F. Bickford, 773-A

C. A. Cicero, $773-41 \mathrm{~A}$

C. L. Crawford, 773-41A

D. M. Ferrara, 773-A

B. C. $\mathrm{Ha}, 773-41 \mathrm{~A}$

J. R. Harbour, 774-43A

B. J. Hardy, 773-41A

D. T. Herman, 773-41A

C. M. Jantzen, 773-A

A. L. Kielpinski, 773-41A

J. C. Marra, 773-A

K. E. Mottel, 773-43A

J. Pareizs, 773-43A

W. G. Ramsey, 773-A

R. F. Schumacher, 773-41A

F. G. Smith, 704-1T

G. G. Wicks, 773-A

J. H. Holbrook, Westinghouse Hanford Company (5) TIM (4) 